\title{
Az ideálkép és a valóság: (jogi kari) hallgatói pályatervek változásai az egyetemi életútban ${ }^{1}$
}

\author{
joghallgatók - pályaválasztás - szakmai szocializáció - hivatás
}

Tanulmányomban azt vizsgálom, hogy az állam- és jogtudományi karok hallgatóinak professzióképe miként változik előremenetelük során. Abból indulok ki, hogy a képzés kezdetén a hallgatók egy idealizált képpel bírnak a választott szakról és az arra épülő szakmáról/hivatásról. Ez a kép a képzés során, majd még inkább a végzés után és a munkatapasztalatok hatására változik; az adott szakma/hivatás tényleges helyzete alakítja. A jogtudományi karok hallgatói, különösen a joghallgatók egy magas státuszú és presztízsű hivatás több évszázad alatt kialakult külső és belső képének az elemei alapján azonosítják magukat. Korai pályaválasztásuk következtében az egyetemen végbemenő szakmai szocializációjuk már az első években kialakítja bennük a jogászság ideálképét, mellyel erősen azonosulnak. Kérdés, hogy ennek az ideálképnek milyen a viszonya a valósághoz, mennyire tér el a jogászság különböző szakmai csoportjainak a tényleges helyzetétől.

Az „ideálkép” és a „valóság” viszonyát több empirikus kutatás elemzésével vizsgálom; ezek egy része országos, másik részét a Debreceni Egyetem Állam- és Jogtudományi Karán folytatott hallgatói és alumnikutatások jelentik. Az eredmények segíthetnek a joghallgatók felsőoktatási szakmai szocializációjának a formálásában, alakításában is. Mivel kevés kutatás foglalkozott a joghallgatókkal, jelen tanulmány elsősorban a jelenségek leírására vállalkozik.

\section{Elméleti keretek és kutatási előzmények}

Jelen tanulmány elméleti kereteit a pályaválasztási, a szakmai szocializációra vonatkozó és a professzióval foglalkozó elméletek jelentik. Ezek rendkívül szerteágazóak, így csak azokat az összefüggéseket emelem ki, melyek az általam elemzett empirikus kutatások szempontjából relevánsak.

* Fónai Mihály egyetemi tanár, Debreceni Egyetem Állam- és Jogtudományi Kar Közpolitikai és Alkalmazott Szociológiai Tanszék, fonai.mihaly@law.unideb.hu.

A mű a KÖFOP-2.1.2-VEKOP-15-2016-00001 azonosító számú, „A jó kormányzást megalapozó közszolgálat-fejlesztés" elnevezésű kiemelt projekt keretében, a Nemzeti Közszolgálati Egyetem és a Debreceni Egyetemen működő DE ÁJK Állami Erőforrások Államtudományi Kutatóműhely együttműködésével készült. 
A pályaválasztási elméletek átfogó elemzésével több hazai kutató is foglalkozott. $^{2}$ Az elméleti megközelítéseket megközelítésmódjuk és föbb kérdésfeltevéseik alapján csoportosították, ezek a következők: klasszikus pályaalkalmassági, pszichodinamikai, fejlődéselvű, döntés és pályaszocializációs elméletek. ${ }^{3} A$ tanulmányban elemzett empirikus kutatások eredményeinek az értelmezéséhez a fejlődéselvet hangsúlyozó magyarázó modellek közül Ginzberg elméletét vehetjük figyelembe, aki három fejlődési szakaszt, a fantázia, a próbaválasztás és a realisztikus fejlődési szakaszt különítette el, mint amelyek a pályaválasztási döntéssel kapcsolatosak. ${ }^{4} \mathrm{~A}$ harmadik szakasz a pályára állásé, a pályakezdésé, amelyre az jellemző, hogy az egyén kompromisszumot köt vágyai és lehetőségei ismeretében. Dolgozatom alapkérdése épp az, hogy mennyiben jellemzi a joghallgatókat és a fiatal jogászokat az, hogy az ideák vagy a valóság alakítják a hivatással kapcsolatos véleményüket és elvárásaikat. A Ginzberg által felvetett kompromisszum alapján az várható, hogy mind az ideák, mind a valóság szerepet játszanak a pályaválasztásban, illetve a hivatás megítélésében.

A pályaválasztási elméletek közül a pályaszocializációs elméletek néhány megállapítását és eredményét vehetjük még figyelembe, különösen Daheim és Musgrave állításait. ${ }^{5}$ Daheim a pályakijelölés folyamatát három lépcsőfokra bontja, e döntések az iskolai képzésről, a foglalkozásról és a tényleges tevékenység kiválasztásáról szólnak, a döntésekben egyre kisebb szerepe van a családnak, és egyre több szerepe a munkatársaknak, valamint a szakmai kapcsolatoknak. Daheim elmélete alkalmas lehet épp a döntésekre ható aktorok és intézmények hatásának a magyarázatára, illetve a nappali és a levelező tagozaton végzettek közötti különbségek értelmezésére.

Tanulmányomban sokat foglalkozom ezen túl az anticipatív szocializáció kérdésével, melynek jelenségét Musgrave kutatta. Az anticipatív szocializáció a szakmai szocializációs folyamatot négy szakaszra bontja, az előzetes pályaszocializációra (a látens szerepek tanulásával), a pályára kerülésre, melyről az egyén a meglévő szereptapasztalatai és preferenciái alapján dönt, a szakmai szocializációra, amelynek során az adott pálya jellemző szerepmagatartásának megtanulása történik, valamint a harmadlagos szocializációra pályamódosítás esetén. ${ }^{6}$ Empirikus kutatásaink az első két szakasz jellegzetességeit vizsgálják a jogtudományi karok hallgatóinak és a végzettek körében. E kutatásokat beillesztem az „ideálkép - valóság”

\footnotetext{
2 ZAKAR András: Pályaválasztási elméletek. Tankönyvkiadó, Budapest, 1988; SzILÁGYı Klára: $A$ tanácsadási elméletek. GATE Tanárképző Intézet, Gödöllő, 1993; SzILÁGYı Klára: A fiatalok és a felnőttek pályaorientációs és karrierépítési készségeinek szintje, fejlesztésének lehetőségei. Felnőttképzési Kutatási Füzetek, Budapest, 2005; ВаRкó Endre: Pályapedagógia. Szaktudás Kiadó Ház, Budapest, 2006; KovÁcsné Tóth Ágnes: Pályaválasztási motiváció értékrendi alapjai diplomás ápoló és tanárképző főiskolai hallgatók körében. PhDdisszertáció, Semmelweis Egyetem Patológiai Tudományok Doktori Iskola, Budapest, 2007; PAPULA Lászlóné: Mi leszel, ha nagy leszel? A pályaválasztást meghatározó tényezők. Bolyai Szemle, 2008/1, 33-44; HegYI-Halmos Nóra: Mi a pálya? Az iskolai pályaorientáció szerepe és gyakorlata a hazai gimnáziumokban. ELTE Eötvös Kiadó, Budapest, 2018.

3 Lásd SzILÁgyi: i. m., 18-24 és Hegri-Halmos: i. m., 21.

4 Lásd SzIlágyl: i. m., 18 és Hegyl-Halmos: i. m., 26.

5 Hegri-Halmos: i. m., 34-35.

6 Hegri-Halmos: i. m., 35.
} 
dinamikájába, ami módot ad a preferenciák és az attitüdök vizsgálatára, amelyek kapcsán utalok a látens szakmai szocializáció föbb preferenciáira és értékeire is. ${ }^{7}$

A pálya, illetve szakmai szocializáció a pályaválasztástól részben elkülönülő kérdésekkel is bír, hisz a felsőoktatási szocializációval foglalkozó elméletek egy jelentős része a hallgatói szocializációt a szakmai szocializáció kezdeti szakaszának tekinti, azt a folyamatot jelenti, amely során az egyén megszerzi azt a tudást, elsajátítja azokat a készségeket és attitüdöket, amelyekkel szakmai közössége tagjává válhat. ${ }^{8}$

A felsőoktatási szocializációt sokan Astin I-E-O lineáris struktúrájára építik. ${ }^{9} \mathrm{Az}$ input a belépő hallgató családi háttere, vélekedése, értékrendje, korábbi tapasztalatai, a környezet az intézményi struktúra és kultúra, a folyamat kimenete pedig az a változás, mely a hallgatókban végbement (tudásukban, értékeikben, vélekedésükben). Ahogy arra utaltam, jelen írásban és az alapját alkotó empirikus kutatásokban is nagy szerepet szántunk az anticipatív szocializációnak. E kérdést illetően a szakirodalomban nagy viták vannak, ezeket foglalja össze Pusztai Gabriella. ${ }^{10}$

A vélemények egyik csoportja az, mely az egész felsőoktatási szocializációt a szakmai szocializáció anticipáló szakaszával azonosítja, a másik áláspont szerint a felsőoktatás első szakasza a hallgatói szerepek elsajátítását jelenti, és csak a képzés legutolsó fázisa tekinthető az anticipációs szakasznak. ${ }^{11} A z$ európai kutatók esetében gyakran a társadalmi reprodukció, a pályaszocializáció és a tanulmányi tapasztalatok kutatásával összefüggésben kerül elő a hallgatói szocializáció kérdése. A tanulmányban elemzett empirikus kutatások esetében ez a kérdés a nappali és levelező tagozatos hallgatók és az e tagozatokon végzettek közötti különbségekben fogható meg, a hallgatók társadalmi reprodukciójában, vagy például a hivatásra vonatkozó ,jövőbeli elvárások” lényeges eltéréseiben, jelentős mértékben a tapasztalatok és a hallgatói-munkavállalói identitás eltéréseiben.

A jogászságot értelmezhetjük a professzió- és a hivatás(rendi) elméletek kontextusában is. ${ }^{12} \mathrm{~A}$ professziók, "hivatások” kialakulását a szakirodalom történeti folyamatként értelmezi, azt az európai egyetemek kialakulásának és történetének a folyamatába ágyazva tárgyalja, ami magyarázatot ad az egyes professziók jellegze-

7 Más hallgatói közegben vizsgálja ezeket a jelenségeket GYöRFFY Zsuzsa-SusÁnSZkY Anna-SzÁNTó ZsuzsaSuSÁNSZKY Éva: Az orvosi pályaválasztás átalakulása - Mit mutatnak a terepmunka-tapasztalataink? Metszetek, 2017/2, 5-21, illetve általánosabban, az értékek oldaláról: Bocsı Veronika: A felsőoktatás értékmetszetei. Új Mandátum Kiadó, Budapest, 2016.

8 Koltóı Lilla: Hallgatók társas és tanulmányi integrációjának hatása a szakmai szocializációjukra. Felsőoktatási Mühely, 2014/3, 53-66.

9 http://uwm.edu/saassessment/assessment-cycle-reports/ieo-model/; Astın, Alexander W.: Assessment for Excellence: The Philosophy and Practice of Assessment and Evaluation in Higher Education. American Council on Education/Oryx Press Series on Higher Education, Washington, DC, 1991.

10 PusztA Gabriella: Kollegiális kezek a felsőoktatásban. Az értelmező közösség hatása a hallgatói pályafutásra. Akadémiai doktori értekezés, 2010, 24-35.

11 Pusztal: i. m., 25.

12 Összefoglalóan FónAı Mihály: Joghallgatók - Honnan jönnek és hová tartanak? Debreceni Egyetem ÁJKDELA Kiadó, Debrecen, 2014. 
tességeire is. ${ }^{13} \mathrm{E}$ professziók története nagy hatást gyakorolt mai arculatukra is, a professziók jellegzetes társadalmi helyzetére, jellegzetes összetevőire, hisz karakterük és társadalmi helyzetük évszázadok óta keveset változott. Azt a magas fokú autonómiára törekvés, a laikusoktól való elkülönülés, a magas társadalmi státusz és presztízs, valamint a mindezeket magába foglaló, hivatási, hivatásrendi tudat jellemzi. ${ }^{14}$

A professziók szociológiai elemzésének egyik meghatározó irányzata a funkcionalista, amelynek föbb állításait Parsons fogalmazta meg, az ő munkássága nyomán terjedt el a szakirodalomban a professziók kritériumaként a szakmához szükséges tudás meghatározásának szükségessége, annak adott képzőhelyeken való elsajátítása, a jogilag rendezett körülmények közötti munkavégzés, valamint a szakmai készségek monopóliumáról elfogadott formális etikai kódex. ${ }^{15} \mathrm{~A}$ funkcionalista irányzat a professziók kialakulását valamilyen társadalmi folyamathoz, és annak a professzióra gyakorolt hatásához köti, ha a társadalom számára „szükséges”, a professzió kialakul. Emellett kiemelték a professziót átfogó etikai normák és az azt garantáló mechanizmusok, szervezetek fontosságát, valamint a professzióhoz szükséges tudás átadását az oktatásban (arról is megegyezés szükséges, hogy mi ez a tudás).

Az interakcionista irányzat ezzel szemben máshova helyezte a hangsúlyokat, éspedig a professzionális hatalomra, valamint a professziókra mint társadalmi aktorokra. A hatvanas és a hetvenes évek kutatásai e jelenségeket leginkább az orvosok professziója kapcsán mutatták ki, ezért foglalkozik nagyszámú teoretikus és empirikus munka az orvosokkal. ${ }^{16}$ Eddigi kutatásaim során a jogászságot mint professziót, hivatást és a weberi értelemben vett hivatásrendet vizsgáltam, nagy hangsúlyt fektetve a hivatás presztízsére, magas státuszára, autonómiájára, illetve ezeknek a kritériumoknak az érvényesülésére a joghallgatók és a fiatal, friss diplomás jogászok professzióképében. ${ }^{17}$

A tanulmányban elemzett kérdéseket alig kutatják a hazai jogszociológiában, ezek eredményeit több írásban összefoglaltam. ${ }^{18} \mathrm{~A}$ hallgatók professzióképének elemeit és a pályaválasztás kérdéseit, motivációit Feith Helga és Badó Attila vizsgálta, majd a 2000-es kutatás kérdőívét Badó Attila és munkatársai újra alkalmazták a szegedi joghallgatók körében. ${ }^{19}$ A 2000 -es kutatásban a pályaválasztási motívumok

13 PARsons, Talcott: Professions. In: Shills, David (ed): International Encyclopedia of the Social Sciences. Mac Millan and Free Press, Vol. 12, 1968, 536-547; Le Goff, Jaques: Az értelmiség a középkorban. Magvető, Budapest, 1979.

14 Weber, Max: Politikai közösségek. In: Weber, Max: Gazdaság és társadalom. Szemelvények. Közgazdasági és Jogi Könyvkiadó, Budapest, 1967, 241-256.; P. SzABó Béla: Jogászság és jogászképzés. In: Szabó Miklós (szerk.): Bevezetés a jog-és államtudományokba. Bíbor, Miskolc, 2012, 35-62.

15 PARSOns: i. m., 536-547.

16 Freidson, Eliot: Profession of Medicine. A Study of the Sociology of Applied Knowledge. Dodd, Mead \& Company, New York, 1970.

17 FónAl (2014): i. m., 12. lábjegyzet.

18 FónAI (2014): i. m., 12. lábjegyzet, valamint FónAI Mihály-BARTA Attila-GYüRE Annamária Csilla-PÉnZEs Ferenc: A joghallgatók rekrutációja és professzióképének néhány eleme. Pro Futuro, 2014/2, 11-37.

19 Feith Helga-Badó Attila: Magyar joghallgatók motivációs vizsgálata. Jogelméleti Szemle, 2000/4, <http:// jesz.ajk.elte.hu/bado4.html> (2018. 07. 08.); BADó Attila-FELEKY Gábor-LőRINCZI János-PATYI Zsófia: Összehasonlító motivációs vizsgálat a szegedi joghallgatók körében. MTA Law Working Papers, 2017/11. 
három tényező köré csoportosultak: a családi, baráti, személyes hatások, a jogi pályák presztízse és anyagi lehetőségei, a biztos álláslehetőségek, valamint a jogászi szakmával összefüggő olyan tényezők, mint a ,jogélet rejtelmei”, az igazságszeretet. Ezek a motívumok azt mutatják, hogy a hallgatókra a jogász pályák magas státusza és presztízse nagy hatást gyakorolt - amikor ezekre a tényezőkre direkten kérdeztek rá, egyértelmü volt a státusz, a presztízs, a távlati lehetőségek, a jó kereset és a doktori cím erős vonzása, és hasonlóak voltak a jogászi hivatás melletti joghallgatói érveknek a mintázatai is. ${ }^{20}$ Badóék a 2016-os kutatásuknak a szegedi joghallgatók körében folytatott adatfelvétele kapcsán arra a megállapításra jutottak, hogy „1996-hoz képest a joghallgatók inkább racionális szempontok alapján, és döntésüket korábban meghozva készülnek a jogi pályára. Az adatok alapján szignifikánsan növekvő szerepe figyelhető meg a jogi pályát választóknál a doktori címnek, a pálya presztízsének, illetve a szülői, testvéri vagy baráti példának.” „A joghallgatók életstratégiái húsz év alatt nem változtak lényegesen, a prioritási sorrend gyakorlatilag ugyanaz: sikeres szakmai karrier, átlagon felüli vagyon, kettő vagy több diploma, „Summa cum laude« minősítésủ diploma, nagycsalád és mindkét adatfelvételkor a politikai karrier volt a legkevésbé fontos."21

\section{Hipotézisek}

Hipotéziseimet az elméleti keretek és a kutatási előzmények alapján fogalmazom meg. Fontosnak tartom megjegyezni, hogy jelen tanulmányban a hallgatók és a frissdiplomások családi hátterének, a szociodemográfiai változóknak a hatását nem elemzem, ez a lehetséges hipotéziseket is befolyásolja. A szociodemográfiai változók hatásáról a felsőoktatási életútra több magyarázat is született, ezek alapján a felsőoktatási életútra a hallgatók családi, társadalmi hátterének hatása nem közvetlen, még ha a kutatók egy része a közvetlenebb hatás mellett is érvel. ${ }^{22} \mathrm{Hipo}$ téziseim ennek megfelelően a pályaválasztásra, a felsőoktatási szocializációra és a „professzióra” vonatkoznak.

A pályaválasztás kapcsán Ginzberg és Daheim állitásaira támaszkodom ${ }^{23}$. Ginzbergnek a fejlődési szakaszokra vonatkozó elmélete alapján feltételezem, hogy a harmadik szakaszban, a pályára állás szakaszában a fiatal szakemberek kompromisszumot kötnek vágyaik és lehetőségeik ismeretében $(\mathrm{H} 1)$. Daheimnek a pályakijelölés három lépcsőfokára vonatkozó állítása alapján azt várom, hogy a család szerepe csökken a pályaválasztásban, és nő a munkatársak és a szakmai kapcsolatok fontossága, különösen a levelező tagozatosok esetében $(\mathrm{H} 2)$.

A felsőoktatási, szakmai szocializációra vonatkozó hipotéziseimet Astin, Musgrave és Pusztai elméletei alapján állítom fel. ${ }^{24} \mathrm{~A}$ szakmai szocializáció kapcsán el-

20 FEITH-BADÓ: i. m., 4.

21 BAdó et al.: i. m., 38, 39.

22 A vita és az elméletek összefoglaló elemzését lásd PuszTAI: i. m.; CEGLÉDI Tímea: Reziliencia és felsőoktatás: Beteljesül a reziliencia ígérete vagy élesednek a társadalmi egyenlőtlenségek a felsőoktatásban? PhD-diszszertáció, Debreceni Egyetem, Debreceni Egyetem Humán Tudományok Doktori Iskola, 2018.

23 Lásd a 3. és 4. lábjegyzetet.

24 Lásd az 5. és 9. lábjegyzetet. 
sősorban az empirikus kutatások során anticipatív szocializációt vizsgáltam. Magáról az anticipatív szocializációról viták folynak a szakirodalomban, hogy melyik szakaszát jelenti a felsőoktatási szakmai szocializációnak, az egész felsőoktatási szocializációt vagy annak a befejező szakaszát. ${ }^{25}$ Kutatásom során az anticipatív szocializáció átfogóbb megközelítését alkalmazzuk, feltételezve, hogy már a pályaválasztáskor, a tanulmányok kezdetén és a tanulmányok végén, a pályára való beilleszkedés során is érvényesül a jelenség. A szakirodalom és kutatási tapasztalataim alapján azt várom, hogy a ,jövőre vonatkozó várakozások” esetében lesznek tartós, nem változó elemei a „várakozásnak”, és ez a professziókról kialakult és rögzült képpel van összefüggésben (H3).

A hivatásra (professzióra) vonatkozó hipotézisek a magas státuszú professziók presztízsére vonatkozik, alapvetően Max Webemek a „rendekre” vonatkozó elméletére támaszkodva. ${ }^{26}$ Azt várom, hogy a pályaválasztásban és a jövőre vonatkozó várakozásokban a presztízsnek meghatározó szerepe van a joghallgatók és a fiatal jogvégzettek körében (H4), továbbá különbséget feltételezek a joghallgatók és a jogi karok alapszakos hallgatói között (H5).

\section{Módszer és minta}

Tanulmányomban több országos adatbázis és a Debreceni Egyetem Állam- és Jogtudományi Karán folytatott kutatás eredményeit elemzem. Ezek mindegyike kérdőíves adatfelvétel volt. Az országos Diplomás Pályakövető Rendszer (a továbbiakban: DPR) keretében 2009-ben és 2010-ben kérdezőbiztosok bevonásával, országos reprezentatív mintákon indultak az adatfelvételek, aktív hallgatók és „frissdiplomások” bevonásával. A „frissdiplomás” megnevezést a DPR-kutatás célcsoportjára alkalmazták, azokat értették alatta, akik a kérdőíves megkeresés előtt egy, három, illetve öt évvel végeztek. Az e tanulmányban elemzett 2015-ös országos adatbázis „frissdiplomás” kutatása már online kérdőív alkalmazásával történt, ami alapvetően befolyásolta a válaszolók arányát (az online kérdőíves megkeresésre a 2011-es DPR-mérések bevezetésekor tértek rá). A Debreceni Egyetem Állam- és Jogtudományi Karán (a továbbiakban, ha egyértelműen a karra vonatkoznak az adatok, az ÁJK vagy kar megnevezést használom) 2001-től önkitöltős kérdőíveket alkalmaztunk, 2001 és 2008 között a végzett hallgatók esetében ez postai kérdőív volt. Az elsőéves hallgatók körében folytatott adatfelvételünk első két évében (2006-ban és 2007-ben) önkitöltős kérdőívet használtunk, melyet a hallgatók (önkéntesen) a felvételi beiratkozáskor tölthettek ki. A 2008-as akadémiai évtől a karon az EvaSys online kérdőív használatára tértünk át, ezt hamarosan az egyetem több kara is átvette (az

25 Lásd a 10. lábjegyzetet.

26 Lásd ehhez Weber: i. m.; Feith-Badó: i. m.; Badó et al.: i. m.; Fónal: i. m. (12. lábjegyzet); Fónal Mihály: A jogiés igazgatási képzési területen végzettek elhelyezkedésének presztízs-szempontjai. In: Garai Orsolya-Horváth Tamás-Kiss László-Szép Lilla-Veroszta Zsuzsanna (szerk.): Diplomás pályakövetés IV. Frissdiplomások. Educatio Társadalmi Szolgáltató Nonprofit Kft. Felsőoktatási Osztály, Budapest, 2010, 227-244; Utasi Ágnes (szerk.): Ügyvédek a gyorsuló időben. Belvedere Meridionale, Szeged, 2016. 
alkalmazott kérdőívvel együtt). A karon 2014-ben online kérdőívvel kerestük meg az aktív és a végzett hallgatókat; e kutatás célja e két hallgatói csoport rekrutációjának, professzióképének, jövőképének, elvárásainak és munkaerőpiaci tapasztalatainak a feltárása volt.

A 2009-es, országos „aktív hallgatói” és a 2010-es országos „frissdiplomás” kutatást reprezentatív mintaválasztással folytatták le. A többi országos és kari kutatásnál az összes érintett hallgatót megkeresték, illetve megkerestük, közülük eltérö mértékben válaszoltak a kérdőívre, ezek a mérések nem mintaválasztáson alapultak, ami az eredmények általánosíthatóságát befolyásolta (az országos kutatások adatbázisait súlyozták). A továbbiakban az elemzett minták néhány főbb jellemzőjét ismertetjük (az országos adatfelvételek esetében csak a jogi és igazgatási képzési területre vonatkozó számításokat végeztünk, illetve több esetben leválogattuk a joghallgatókat, jogi végzettségüeket).

\section{Hallgatói motivációs kutatás $2009^{27}$}

A kutatás populációját (alapsokaságát) az államilag elismert felsőoktatási intézmények nappali alap- és osztatlan képzésben részt vevő hallgatói jelentették. A mintavétel képzésterület, szak, évfolyam és nem szerint történt, az egyes karokon arányos kvótás mintavétellel és intézményi almintákkal. A minta nagysága 7835 fő volt.

Diplomás kutatás $2010^{28}$

A tíz képzési területre kiterjedő kutatás a 2007-ben végzetteket érintette (49 382 főt). Közülük egyszerü véletlen mintaválasztással alakítottak ki egy 4879 fős mintát, a tényleges minta a lekérdezés után 4507 fös volt.

\section{Frissdiplomások $2015^{29}$}

Az adatfelvétel a 2010., 2012. és a 2014. évben abszolutóriumot szerzett hallgatókat érintette. A vizsgálatban részt vevő 34 intézmény 182299 frissdiplomását keresték meg, az online kérdőíves megkeresésre közülük 20579 fö, azaz 11,3\% válaszolt.

Végzettek „utánkövetése”, DE ÁJK, 2001-2008

A Debreceni Egyetem Állam- és Jogtudományi Karán 2001 és 2008 között került sor a végzett hallgatók „utánkövetéses” vizsgálatára. A végzés után egy évvel megkerestük a végzett hallgatókat, a családi hátterükről, a pályaválasztás, majd a munkahelyválasztás okairól és körülményeiröl, valamint a képzésről kérdeztük őket. Az „utánkövetés” igen sikeres volt, az érintett időszakban végzett hallgatóink mintegy 30 százaléka, 425 fő válaszolt, ami magas arány az alkalmazott postai kérdőíves módszer esetében, ami azt is eredményezte, hogy a magas válaszadási arány

27 Diplomás pályakövetés - hallgatói motivációs kutatás 2009. Módszertan. Educatio Társadalmi Szolgáltató Nonprofit Kft.

28 Diplomás kutatás 2010, Módszertani leírás. Educatio Társadalmi Szolgáltató Nonprofit Kft.

29 Veroszta Zsuzsanna: Diplomás Pályakövetési Rendszer országos kutatás. Oktatási Hivatal Felsőoktatási Elemzési Főosztály, 2016. szeptember. 
következtében elfogadhatóan pontos képet kaptunk a karon végzett hallgatókról, függetlenül attól, hogy a kutatás nem reprezentatív adatfelvételen alapult.

\section{DE ÁJK, „gólya”-mérések 2006-2008}

Az alumnikutatásaink, valamint a Debreceni Egyetem Tehetséggondozó Programjának (DETEP) a tapasztalatai alapján terveztük és szerveztük meg a "gólyavizsgálatot", melyre a 2006 és 2008 közötti három akadémiai évben került sor. Ezt követően a DE minőségbiztosítási rendszerén belül a "tudományegyetemi karok” mindegyikén alkalmazták a karon kidolgozott kérdőívet. Jelen tanulmányban a csak az ÁJK-on lefolytatott adatfelvételek eredményeit elemzem. Az elsőévesek közül e három évben 1215 fő válaszolt, a beiratkozott hallgatók több mint fele (58\%-a).

DE ÁJK, aktív hallgatói és frissdiplomás kutatás 2014

A vizsgált évben a karon a 2014-es márciusi intézményi statisztika alapján 2063 aktív hallgató tanult, közülük 1872 föt kerestünk meg (ennyi hallgatónak volt elérhető e-mail-címe), közülük 129 fö válaszolt, ami 6,9\%-os visszaküldési arány, valamivel alacsonyabb, mint az országos DPR-méréseké volt (mára ezek esetében is hasonló a visszaküldési arány).

A végzett hallgatók körében a 2007 után végzettek elérése látszott reálisnak, a hallgatói e-mail-címek megléte miatt. Ebben az időszakban (2007-2014 között) a karon 2631 fö végzett (valamint 385-en a szakirányú továbbképzésekben), közülük csak 1041 fő volt elérhető (e tapasztalatok miatt vezették be az e-mail-címek kötelező megadását a hallgatói beiratkozáskor, például 2010 után az országos DPR-kutatások céljaira is). A megkeresett végzett hallgatók, az elterjedt megnevezés szerint "frissdiplomások” közül 128 fő válaszolt, ami 12,3\%-os arány (a „frissdiplomás” megnevezést az országos DPR-kutatásokban használják, 2010 óta). A DPR-mérések is azt mutatják, hogy a végzettek sokkal nagyobb arányban válaszolnak a képzőhely megkereséseire, mint az aktív hallgatók. Az alacsony elemszámok és az alacsony válaszadási arány miatt következtetéseink általánosítási szintje korlátozott, a Debreceni Egyetem Állam- és Jogtudományi Kara esetében is csak az alapvető trendek megrajzolására alkalmas, a jogi kari képzések és a frissdiplomások általánosabb jellemzése óvatosságot igényel.

\section{Empirikus eredmények}

\subsection{A hallgatók pálya- és szakválasztása}

A szakirodalom alapján a pálya- és szakválasztásra számos szereplő és tényező hat, ezek egy része személyes és informális hatás, egy része formális, intézményes hatás. Elsőként azt vizsgálom, hogy mi motiválta a szakok választását a frissdiplomások szerint (1. táblázat). 
1. táblázat. A szakra való jelentkezés motivációja, képzési területenként (százalékban). (Diplomás kutatás 2010) (30 $^{30}$

\begin{tabular}{|c|c|c|c|c|c|c|}
\hline & 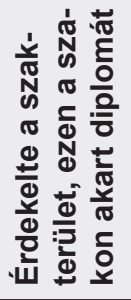 & 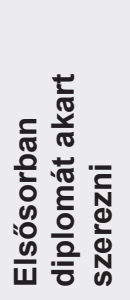 & 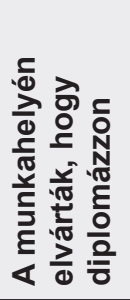 & 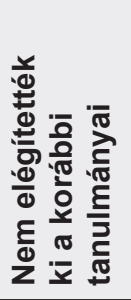 & 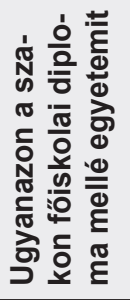 & 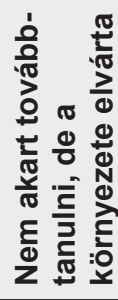 \\
\hline Agrár & 72,8 & 16,0 & 6,3 & 1,4 & 0,3 & 0,8 \\
\hline Bölcsészettudomány & 70,6 & 14,6 & 5,0 & 4,1 & 2,8 & 0,9 \\
\hline Gazdaságtudomány & 73,9 & 15,2 & 3,2 & 1,6 & 0,3 & 0,4 \\
\hline Informatika & 84,9 & 5,3 & 3,8 & 1,3 & 3,5 & 0,6 \\
\hline Jogi és igazgatási & 74,9 & 9,3 & 6,2 & 5.4 & 0,5 & 0,3 \\
\hline Müszaki & 81,4 & 9,4 & 3,0 & 2,1 & 0,6 & 1,3 \\
\hline $\begin{array}{l}\text { Orvos- és } \\
\text { egészségtudományi }\end{array}$ & 84,2 & 5,2 & 6,0 & 0,8 & 1,4 & 0,3 \\
\hline Pedagógusképzés & 77,7 & 9,0 & 4,8 & 5,6 & 0,3 & 0,3 \\
\hline Társadalomtudomány & 69,0 & 16,0 & 7,1 & 2,5 & 0,5 & 0,5 \\
\hline Természettudomány & 86,8 & 3,7 & 2,5 & 2,9 & 2,5 & 0,0 \\
\hline Total $^{31}$ & 76,6 & 11,4 & 4,6 & 2,7 & 1,1 & 0,6 \\
\hline
\end{tabular}

A DPR-kutatás képzésterületi eredményei csak részben igazolják a pályaválasztással kapcsolatos elköteleződésre vonatkozó állításokat, hisz a jogi és igazgatási képzési terület frissdiplomásai (a jogászok mellett az igazgatási alapszakokon végzettek) a diplomás átlagnak megfelelően indokolták választásukat azzal, hogy maga a szakterület érdekelte őket. Leginkább az orvos- és egészségtudományi képzési terület fiatal szakemberei jelezték a magas szintű érdeklődést a szak és a szakma iránt, ami azt is mutatja, hogy a magas státuszú orvosok mellett jelentős a szakma iránti elköteleződés (érdeklődés) más egészségügyi szakemberek körében is, amit gyakran indokolnak e szakmák „hivatástudatával”. ${ }^{22}$ Kiugró elköteleződés tapasztalható még a természettudományi, az informatikai és a müszaki képzési területeken végzettek esetében, ami ugyancsak azt mutatja, hogy az egyes szakmák, hivatások esetében azok státusza és presztízse csak részben magyarázza a (korai és) erős elköteleződést.

30 Forrás: Diplomás kutatás 2010, N = 4508; FónAı Mihály-BARTA Attila-GYüre Annamária Csilla-PÉnZEs Ferenc: A joghallgatók rekrutációja és professzió-képének néhány eleme. Pro Futuro, 2014/2, 26.

31 „Nem tudom” és „nem válaszolt” válaszok nélkül.

32 SÁGI Matild: Az orvosi hivatás. In: Szántó Zsuzsanna-Susánszky Éva (szerk.): Orvosi szociológia. Semmelweis Kiadó, Budapest, 2006, 86-105. 
A karon folytatott korábbi kutatásaink eredményei azt mutatták, hogy a szakma diploma - karrier motiválta a hallgatókat abban, hogy egyetemre jelentkezzenek. ${ }^{33}$ A legtöbb területen a tagozatok alapján figyelhető meg különbség: a nappali tagozatosok választása erősebb kötődést mutat az egyetemi léthez (a DPR-kutatások eredményei is azt jelzik, hogy inkább tartják magukat hallgatónak, míg a levelező tagozatosok legalább annyira tartják magukat munkavállalónak, mint hallgatónak). A 2014-es kari (DE ÁJK) kutatásunk eredményei (a motívumok sorrendjében) nem térnek el jelentősen a korábbi adatfelvételektől, ami a felsőoktatási továbbtanulás motívumainak a tartósságát jelzi, azaz abban, hogy ki és miért jelentkezik egyetemre, nincsenek gyorsan változó motívumok (Mellékletek 1. ábra).

A továbbtanulási döntésre ható tényezők esetében a 2014-es kutatásban a szakok között három területen találunk szignifikáns különbségeket: a joghallgatók inkább látják úgy, hogy azért jöttek egyetemre, mert a szüleik is diplomások (ez megfelel a szakok közötti tényleges különbségnek a szülők iskolai végzettségét illetően). Az alapszakosok választásai között fontos, hogy azért tanulnak, mert a munkájukhoz és a munkahelyi előmenetelükhöz szükség van az egyetemi végzettséghez. A szaknál sokkal erőteljesebb hatást gyakorol a továbbtanulási döntésre a tagozat, a karrier kivételével minden motívum esetében szignifikáns különbség érvényesül a nappali és a levelező tagozat között. A nappali tagozatos hallgatók és frissdiplomások inkább tűnnek kredencialistának („fontos a diploma”), a levelező tagozatosok pedig „biztonsági játékosnak”, akik azért tanulnak egyetemen, mert az a munkájuk és az előmenetelük miatt fontos, ami azt is magyarázza, hogy miért érdekli inkább a levelező tagozatosokat a választott szakma, hisz jelentős részük olyan területen dolgozik, amit az egyetemen tanul.

A felsőoktatási továbbtanulással összefüggő döntések között több kutatásunkban is vizsgáltuk azt, hogy a szak választására egyes tényezők és személyek milyen hatást gyakoroltak. Hasonlóan a továbbtanulási döntéshez, a szakválasztás esetében is megfigyelhetők trendszerü folyamatok. Jellemzőnek tűnik az elképzelések megvalósításának a szerepe, emellett a diploma előnyei azok, melyek a választásra hatnak (1. ábra). A válaszolók úgy találták, hogy más személyek, a család és az iskola, a tanárok kisebb szerepet játszottak abban, hogy például a jogász szakot választották. Ez meglehetősen nagy fokú önállóságot és tájékozottságot feltételez, viszonylag korán kialakuló pályaválasztási döntéssel, a szakmával, hivatással való korai azonosulással és elköteleződéssel. 


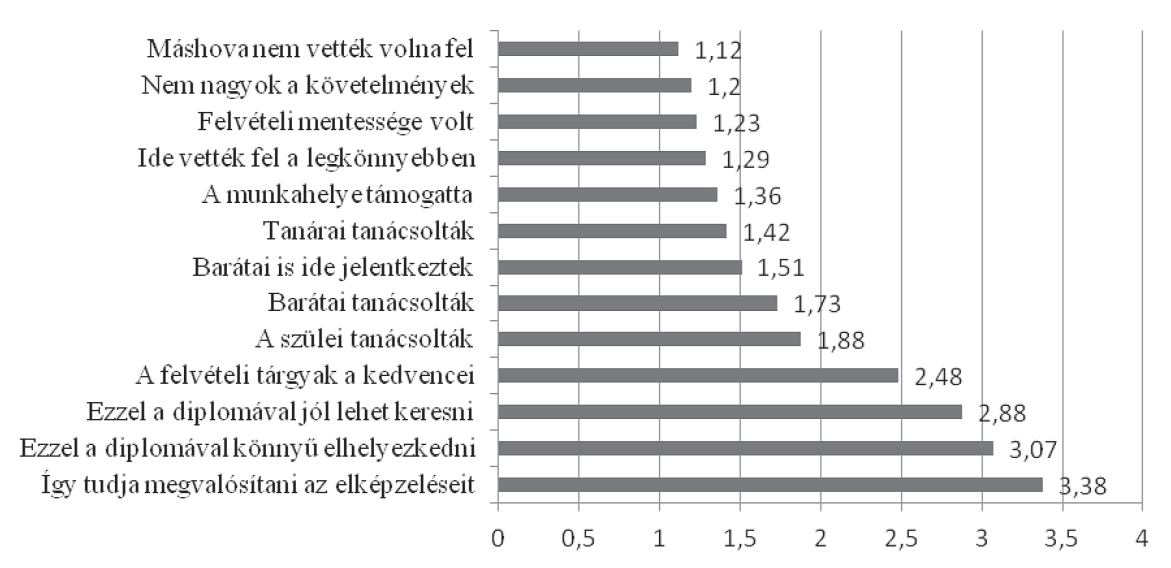

1. ábra. A táblázatban szereplő tényezők hatása a szak kiválasztásában (négyfokozatú skálán). (DE ÁJK 2014) ${ }^{34}$

A joghallgatók és az alapszakosok véleménye között csak két területen érvényesült szignifikáns eltérés. Az alapszakosok inkább gondolják azt, hogy a barátaik tanácsa is alakította pályaválasztásukat, míg a joghallgatók döntését föleg az befolyásolta, hogy a diplomával jól lehet keresni. A tagozatok között már több jelentős különbség érvényesül, ezeket az eltérő élethelyzet és életkor is alakítja. A nappali tagozatos és azon végzett hallgatók nagyobb fontosságot tulajdonítanak a család hatásának, ők gondolják inkább azt, hogy a diplomával jól lehet keresni. A levelező tagozatosok sokkal kisebb külső hatást neveznek meg a pályaválasztásukban, mint a nappali tagozatosok, és érthetően esetükben jellemzőbb a munkahely támogató szerepe. Bár a diploma/végzettség előnyei nagyon fontosak a jogi kari hallgatók szakválasztási motívumai között (ez a „valóság”), az „ideálkép” is hat a választásra (elképzelések megvalósítása), sőt ez a legfontosabb dolog a motívumok között. Ugyanakkor már a pályaválasztás időszaka és az akkor érvényesülő hatások, célok, elképzelések is azt mutatják, hogy egyszerre érvényesülnek az ideálképpel összefüggő és az azzal kevésbé jellemezhető, materiális tényezők a választásban.

\subsection{Elvárások és jövőkép}

Az állam- és jogtudományi karon belül a jogászhallgatók jövőre vonatkozó elvárásainak, szakmai anticipációinak a föbb vonásai nem különböznek lényegesen a szak (szakma) választására vonatkozó válaszaiktól. Az egyetem elvégzése utáni tervekre vonatkozó kérdésre adott válaszok két dimenzióba sorolhatók, az általánosabb motívumok csoportjába és a konkrét jogi, igazgatási foglalkozások, munkakörök csoportjába (M1. táblázat).

${ }^{34}$ Forrás: DE ÁJK aktív és végzett hallgatók kutatása, 2014. 
A DE ÁJK elsőéves hallgatóinak anticipációit alapvetően az jellemzi, hogy a „szakmában helyezkednének el”, illetve újabb diplomát szereznének, ez leginkább az igazgatásszervező nappali tagozatos hallgatókra jellemző; tapasztalataink alapján ez az újabb diploma a jogászi, ami a jogász hivatások vonzerejét is mutatja. A „szakma” vonzása, mint a jövőkép meghatározó eleme, már a szakválasztáskor is érvényesült a hallgatók körében - ahogy arra utaltam -, ez egy erős motívumot és mozgatórugót jelent, ami a választott szakkal (szakmával) való jelentős azonosulásból is fakad. Az általánosabb jövőtervek között a karrier inkább a levelező tagozatos hallgatókat jellemzi, esetükben ez egy erős tanulási és anticipációs mozgatóerő is, hisz a terveiket, benne a diplomát és a karriert csakis az egyetemi tanulmányokkal érhetik el, ám a karrier lehetősége (a tanulmányok révén) legalább ennyire erős motívum.

A konkrét jogi és igazgatási szakmák, munkakörök közül az elsőéves joghallgatókat föleg az ügyvédi pálya vonzza, a bírói, ügyészi vagy közjegyzői pályák kevésbé vonzzák őket. Ez következhet az e hivatásokra való bekerülés esélyéből, illetve az esélyre vonatkozó vélekedésből is, amit az eltérő módszertannal feltett kérésekre adott válaszok eltérései is igazolnak, ahogy azt még a későbbiekben elemzem. A közigazgatás alig gyakorol hatást a joghallgatókra. Ezzel szemben - a szakmájuk adta lehetőségek miatt is - az igazgatásszervező szakos hallgatók ${ }^{35}$ inkább a közigazgatásban dolgoznának (ezt támasztja alá a „szakmában helyezkedne el” válaszok aránya is). A "gólya"-kutatás harmadik évében módosítottuk az alkalmazott kérdőívet, a korábbi évek tapasztalatai alapján külön-külön kérdeztünk rá az egyes foglalkozásokra, szakmákra, illetve az általánosabb motívumokra. Jelen tanulmányban a foglalkozásokkal, hivatásokkal, munkával kapcsolatos konkrét kérdéseket elemzem (2. táblázat).

2. táblázat. A DE ÁJK elsőéves hallgatóinak választásairól szóló adatok a végzés utáni terveikkel kapcsolatban és arra vonatkozóan, hogy az egyes kijelentések megfelelnek-e a terveiknek

(az adott kijelentést elfogadók aránya, \%).

(DE ÁJK „gólya”-kutatás 2006-2008, második szakasz) ${ }^{36}$

\begin{tabular}{|l|c|c|c|}
\hline & Jogász szakos & $\begin{array}{c}\text { Igazgatás- } \\
\text { szervezö szakos }\end{array}$ & $\begin{array}{c}\text { Összes } \\
\text { elsőéves }\end{array}$ \\
\hline Közigazgatás, államigazgatás & 51,9 & 87,9 & 70,3 \\
\hline $\begin{array}{l}\text { Vállalkozásban alkalmazottként } \\
\text { dolgozni }\end{array}$ & 59,2 & 70,1 & 64,8 \\
\hline Újabb diploma & 49,3 & 65,7 & 57,6 \\
\hline EU-s állás & 53,4 & 61,4 & 57,4 \\
\hline Külföldön dolgozni & 46,1 & 53,6 & 49,9 \\
\hline
\end{tabular}

35 A „gólya”-kutatás akkor zajlott, amikor a karon jelentős számú igazgatásszervező alapszakos hallgató tanult, e szakot jelenleg csak a Nemzeti Közszolgálati Egyetem indíthatja.

36 Forrás: DE ÁJK „gólya”-kutatás 2006-2008. FónAI (2014): i. m., 101. 


\begin{tabular}{|l|c|c|c|}
\hline & Jogász szakos & $\begin{array}{c}\text { Igazgatás- } \\
\text { szervező szakos }\end{array}$ & $\begin{array}{c}\text { Összes } \\
\text { elsőéves }\end{array}$ \\
\hline Közjegyző & 32,7 & 61,9 & 47,3 \\
\hline Jegyző & 29,5 & 54,3 & 42,0 \\
\hline Rendőr & 32,7 & 46,4 & 39,6 \\
\hline Saját vállalkozás & 41,2 & 36,0 & 38,6 \\
\hline Ügyvéd & 53,5 & 14,6 & 33,8 \\
\hline Adótanácsadó & 19,3 & 41,2 & 30,3 \\
\hline Ügyész & 23,9 & 20,4 & 22,1 \\
\hline Bíró & 19,1 & 13,1 & 16,1 \\
\hline Családi praxisban dolgozni & 14,2 & 14,9 & 14,6 \\
\hline Elemszám & $\mathrm{N}=235$ & $\mathrm{~N}=225$ & $\mathrm{~N}=460$ \\
\hline
\end{tabular}

Az M1 (Mellékletek 1.) táblázatban az elsőéves hallgatók választásainak a rangsora jobban érvényesül, a 2. táblázat adatai ehhez képest azt mutatják, hogy a hallgatók mekkora hányada választaná egyáltalán az adott területet, jogi pályát. $\mathrm{E}$ két választás között megfigyelhető néhány jellegzetes különbség. Így például a joghallgatók terveinek megfelelne az, hogy a közigazgatásban dolgozzon, ám ha bizonyos rangsorolásra van mód, a közigazgatás vonzereje jelentősen csökken (ehhez lásd a 3. és a 9. táblázatot). Hozzájuk képest az igazgatásszervező szakos hallgatók konzekvensebbek, a közigazgatással összefüggő pályák vonzzák őket leginkább, emellett a magas továbbtanulási tervek miatt potenciálisan a jogi végzettséget igénylő pályákat is preferálják. A joghallgatók a klasszikus, igazságügyi jogi hivatások közül leginkább ügyvédek lennének, és kevésbé tervezik, hogy bírói vagy ügyészi pályára lépnek. Ugyanakkor fontos hangsúlyozni, hogy a „megfelel-e a tervének, hogy... legyen" kérdésre adott válaszok esetében kifejezetten magas azoknak az aránya közöttük, akik bíróként vagy ügyészként dolgoznának - ehhez képest már "gólya”korukban, az egyetemi beiratkozáskor a hasonló terveket firtató zárt kérdésre, mely a válaszok alapján egyfajta rangsort eredményez, alig válaszolták azt, hogy e hivatásokat választanák a jövőben (M1. táblázat). Ez a jogi pályákhoz való ambivalens viszonyulást mutat, ami az ideálkép-valóság diszkrepanciájának is megfelel; ezt támasztják alá a „munkahelyek presztízsére” (3. táblázat) és a tényleges elhelyezkedésre utaló adatok is (8. táblázat). Mindkét szak hallgatói elképzelhetőnek tartották azt, hogy külföldön dolgozzanak, ez a végzettségek szakmai tartalma alapján nehezen megvalósítható opciónak tünik.

A diszkrepanciák jellemzésére alkalmas a „munkahelyek presztízsére” vonatkozó vélemények (3. táblázat) és a tényleges elhelyezkedési mutatók (9. táblázat) öszszevetése. Elsőként lássuk, hogy a „diplomás 2010” kutatás során milyennek ítélték meg az igazgatásszervező és jogász frissdiplomások az egyes foglalkozásokat, hivatásokat, illetve munkahelyeket (3. táblázat). 
3. táblázat. A munkahelyek presztízse (említések száma).

(Diplomás kutatás 2010) ${ }^{37}$

\begin{tabular}{|c|c|c|c|c|c|c|c|c|}
\hline & \multicolumn{2}{|c|}{$\begin{array}{l}\text { 1. legelis- } \\
\text { mertebb }\end{array}$} & \multicolumn{2}{|c|}{$\begin{array}{l}\text { 2. legelis- } \\
\text { mertebb }\end{array}$} & \multicolumn{2}{|c|}{$\begin{array}{l}\text { 3. legelis- } \\
\text { mertebb }\end{array}$} & \multicolumn{2}{|c|}{$\begin{array}{l}\text { Legkevésbé } \\
\text { elismert }\end{array}$} \\
\hline & 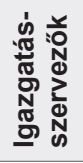 & 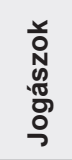 & 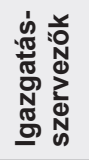 & $\begin{array}{l}\text { ․ } \\
N \\
\mathbb{N} \\
\mathbb{0} \\
0 \\
0\end{array}$ & 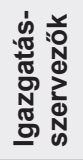 & 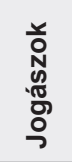 & 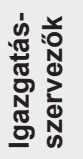 & 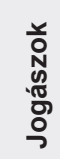 \\
\hline $\begin{array}{l}\text { Egyetem, } \\
\text { főiskola }\end{array}$ & 5 & 18 & 4 & 11 & 7 & 19 & 1 & 12 \\
\hline Kutatóintézet & 1 & 7 & 1 & 12 & 2 & 14 & 10 & 11 \\
\hline Bíróság & 5 & 97 & 4 & 62 & 6 & 26 & 0 & 7 \\
\hline Ügyészség & 2 & 29 & 4 & 85 & 7 & 47 & 2 & 5 \\
\hline Ügyvédi iroda & 1 & 53 & 4 & 27 & 4 & 70 & 1 & 9 \\
\hline $\begin{array}{l}\text { Közjegyzői } \\
\text { iroda }\end{array}$ & 1 & 14 & 3 & 21 & 8 & 33 & 2 & 8 \\
\hline Államigazgatás & 33 & 20 & 16 & 19 & 4 & 21 & 3 & 29 \\
\hline $\begin{array}{l}\text { Önkormányzati } \\
\text { igazgatás }\end{array}$ & 9 & 2 & 24 & 11 & 7 & 6 & 8 & 43 \\
\hline $\begin{array}{l}\text { Gazdálkodó } \\
\text { szervezetek }\end{array}$ & 0 & 12 & 3 & 3 & 15 & 15 & 8 & 28 \\
\hline $\begin{array}{l}\text { Civil } \\
\text { szervezetek }\end{array}$ & 0 & 0 & 0 & 2 & 1 & 0 & 20 & 93 \\
\hline Egyéb & 3 & 2 & 1 & 0 & 0 & 0 & 1 & 0 \\
\hline Elemszám & 71 & 258 & 71 & 257 & 71 & 257 & 71 & 257 \\
\hline
\end{tabular}

A foglalkozások, hivatások, munkahelyek presztízsének a rangsorolása azt mutatja, hogy a frissdiplomások fejében lévő presztízsrangsor már hallgató korukban befolyásolja a szakmai jövőképüket és anticipációikat. Ugyanakkor ez a hatás jól beleilleszthető az „ideálkép-valóság” diszkrepanciájába is, hisz a „reális” jövőkép rangsora (M1. táblázat) az inverze a munkahelyek presztízsrangsorának, ami egy nagyon komoly belső feszültséget generálhat a hallgatókban és a frissdiplomásokban is, a vonzó, nagy presztízsű munkahelyek (foglalkozások és hivatások) és a tényleges lehetőségek között.

A joghallgatók a klasszikus, igazságügyi jogi hivatások presztízsét tartják a legmagasabbnak, minden más területét sokkal alacsonyabbnak, beleértve az egyetemi és kutatóintézeti munkahelyeket is. A gazdasági szervezetek és a civil szervezetek presztízsét nagyon alacsonyra taksálják. Az igazgatásszervezők presztízsrangsorá-

37 Forrás: Diplomás kutatás 2010. Educatio Nonprofit Kft.; FónAl (2014): i. m., 119. 
ban a közigazgatási munkahelyek dominálnak, más munkahelyek presztízsét ők is alacsonynak tartják.

Sok szempontból a presztízsrangsorok a 2. táblázatban szereplő választásoknak felelnek meg, azaz a hallgatók és a fiatal diplomások fejében valóban mintha két „rangsor” volna: egy, a magas presztízsű pályákat preferáló „ideálkép” és egy, a tényleges lehetőségekre reflektáló „valóságkép”, amely mindig visszarángatja őket a realitások talajára. A továbbiakban azt vizsgáljuk meg, hogy milyen mintázatok mutathatók ki a végzés utáni elhelyezkedésben.

\subsection{Az első munkahely választásának szempontjai és módja}

A munkahelyek választásának szempontjait a munkaerőpiaci kereslet és a kínálat ${ }^{38}$ mellett az egyes szakmák, hivatások értékpreferenciái, ${ }^{39}$ benne munka-értékpreferenciái alakítják. ${ }^{40} \mathrm{Ez}$ hat az adott szak(ma) hallgatóinak a jövőbeli elvárásaira és szakmai identitására is, sok szempontból alakítja a szakmáról, hivatásról kialakult ideálképet is. Az első kérdés a végzett hallgató számára nagyon is „technikai”: kell-e munkát, állást keresnie, hisz az a munkával kapcsolatos elvárásait is alakítja, ezért érvényesül lényeges eltérés a nappali és a levelező tagozaton végzettek elvárásai, választási szempontjai és gyakran a munkakeresés módozatai között is. A frissdiplomások 2015-ös országos adatfelvételének eredményei is ezt mutatják (4. táblázat).

4. táblázat. Az abszolutórium megszerzése után közvetlenül keresett-e munkát (\%).

(Diplomás Pályakövető Rendszer 2015) ${ }^{41}$

\begin{tabular}{|l|c|c|c|}
\hline & Jogászok & BA-végzettségüek & Teljes minta \\
\hline Igen & 43,9 & 32,0 & 38,0 \\
\hline $\begin{array}{l}\text { Nem, mert már } \\
\text { akkor is dolgozott }\end{array}$ & 33,0 & 58,5 & 45,6 \\
\hline $\begin{array}{l}\text { Nem, mert folytatta } \\
\text { (kezdte) } \\
\text { tanulmányait }\end{array}$ & 15,8 & 7,0 & 11,4 \\
\hline Nem, egyéb okból & 7,4 & 2,5 & 5,0 \\
\hline Válaszolók száma & 367 & 359 & 726 \\
\hline
\end{tabular}

$p=0,000$

38 Tóthné Sikora Gizella (szerk.): Humán erőforrások gazdaságtana. Bíbor Kiadó, Miskolc, 2004.

39 Bocsı Veronika: A felsőoktatás értékmetszetei. Új Mandátum, Budapest, 2015.

40 FónAı Mihály-Kıss János: The Interrelation of Work-Value Preferences and Students' Image of Profession. Hungarian Educational Research Journal, 2013/1, 15-31.

41 Forrás: Diplomás Pályakövető Rendszer 2015, frissdiplomások adatbázis. 
A jogi képzési terület két nagy szakmai csoportját alkotó jogász szakosok és a többféle BA-szakot átfogó alapszakosok, illetve e területek végzettjei közötti különbséget részben az magyarázza, hogy a BA-alapszakosok esetében magasabb a levelező tagozaton végzettek aránya, másrészt közöttük több azoknak a száma, akik az egyetemi tanulmányaik előtt vagy közben már dolgoztak. Ezek a különbségek alakítják a munkahelyválasztással összefüggő szempontokat is (2. ábra és 5. táblázat).

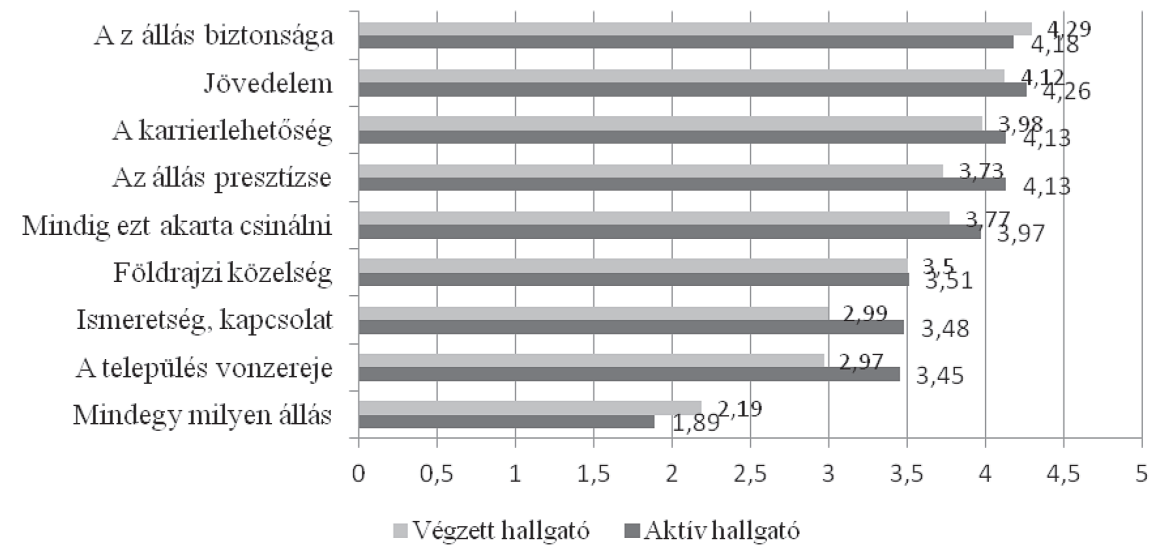

2. ábra. Az első munkahely kiválasztásának szempontjai (ötfokozatú skálán). (DE ÁJK 2014) $)^{42}$

A DE ÁJK 2014-es hallgatói kutatásának eredményei alapján az állás biztonsága, a jövedelem, a karrierlehetőségek és az állás presztízse a meghatározó a munkahely választásában. Jelentős az erős szakmai elköteleződés hatása is, hisz a „mindig ezt akarta csinálni” is fontos szempont. Jelentős különbségek érvényesülnek a még aktív és a már végzett hallgatók között, a végzett hallgatóknak inkább számít az állás biztonsága és a „mindegy, csak legyen” választási opciója a még aktív hallgatókhoz képest. Bár csak a presztízs, az ismeretség és a település vonzereje esetében vannak szignifikáns különbségek, a többi lehetséges szempontot is fontosabbnak tartják az aktív hallgatók. Ez sok szempontból a szakmákról, hivatásokról kialakult „ideálkép kontra valóság” egyik lényeges dimenziója, azaz a kisebb vagy semmilyen munkatapasztalattal bíró aktív hallgatók elvárásai a munkahelyválasztás szempontjai között a magas státuszú hivatásnak szóló anticipációnak felelnek meg. Velük szemben a végzett hallgatók, valószínüleg a nagyobb tapasztalatok miatt is, inkább a „valóságos” helyzetből indulnak ki (a kutatás során „jogi kari hallgatókat” kérdeztünk meg, azaz a joghallgatók mellett a kar alapszakosait, a válaszolók kb. fele-fele arányban voltak a két szak között). ${ }^{43}$

42 Forrás: DE ÁJK aktív és végzett hallgatók kutatása, 2014. Szignifikáns különbségek: presztízs $(p=0,004)$, ismeretség $(p=0,003)$, település vonzereje $(p=0,005)$.

43 FónAI Mihály: Joghallgatók professzió-képe és elhelyezkedésének mintázatai a Debreceni Egyetemen. In: Szikora Veronika-Török Éva (szerk.): Ünnepi tanulmányok Csécsy György 65. születésnapja tiszteletére. Debreceni Egyetem Állam- és Jogtudományi Kar, Debrecen, 2017, 189-204. 
5. táblázat. Az első munkahely választásának szempontjai a jogász frissdiplomások körében, az említések gyakorisága szerint és az összes válasz \%-ban*.

(DE ÁJK „gólya”-kutatás 2006-2008) ${ }^{44}$

\begin{tabular}{|l|r|r|r|r|r|r|}
\hline \multirow{2}{*}{} & \multicolumn{4}{|c|}{ Tagozat } & \multicolumn{2}{c|}{ Teljes minta } \\
\cline { 2 - 6 } & \multicolumn{2}{|c|}{ Nappali } & \multicolumn{2}{c|}{ Levelező } & \multicolumn{2}{c|}{} \\
\hline Az állás biztonsága & 126 & 29,7 & 40 & 25,1 & 166 & 28,5 \\
\hline Nem volt más választása & 54 & 12,7 & 11 & 6,9 & 65 & 11,2 \\
\hline A karrierlehetőség & 44 & 10,4 & 21 & 13,2 & 65 & 11,2 \\
\hline Ismeretség & 43 & 10,1 & 16 & 10,1 & 59 & 10,1 \\
\hline Kereset & 39 & 9,2 & 16 & 10,1 & 55 & 9,4 \\
\hline Földrajzi közelség & 41 & 9,7 & 7 & 4,4 & 48 & 8,2 \\
\hline Mindig ezt akarta csinálni & 27 & 6,4 & 14 & 8,8 & 41 & 7,0 \\
\hline Egyéb & 19 & 4,5 & 14 & 8,8 & 33 & 5,7 \\
\hline A presztízs & 19 & 4,5 & 9 & 5,7 & 28 & 4,8 \\
\hline A település vonzereje & 12 & 2,8 & 11 & 6,9 & 23 & 3,9 \\
\hline Összesen & 424 & 100,0 & 159 & 100,0 & 583 & 100,0 \\
\hline
\end{tabular}

* A válaszok száma több, mint a megkérdezett frissdiplomásoké a többszörös választási lehetőség miatt.

A végzettek esetében az látható, hogy a munkahelyválasztás szempontjait a tényleges lehetőségeken és kényszereken túl a hivatással összefüggő általánosabb elvárások és előfeltevések is alakították - a presztízsre, az önmegvalósításra, az anyagi biztonságra, az immateriális előnyökre (például a település vonzereje) vonatkozó, általánosabb anticipációk révén. A nappali tagozaton végzettek döntéseit sokkal erősebben alakították a kényszerek, ami meglepőnek tünhet, de ha figyelembe vesszük, hogy a levelező tagozaton végzettek többsége már hallgató korában is dolgozik, esetükben kevésbé van szó kényszerdöntésekről; igaz, nagy különbségek lesznek a betöltött állásokban a jogi területeket és beosztásokat illetően. A már kialakult kapcsolatok magyarázhatják azt is, hogy a karrierlehetőségeket is - a végzés után - a levelező tagozaton végzettek tartják fontosabbnak, míg a földrajzi közelség a nappali tagozaton végzetteknél számít inkább, holott ők a mobilisabbak. A tagozatok és a szakok közötti különbségek nemcsak a munkahelyválasztás szempontjaiban érvényesülnek, hanem a módokban, ahogy a frissdiplomások az első munkájukhoz jutnak (6. táblázat, M2. és M3. táblázat).

\footnotetext{
44 Forrás: DE ÁJK végzett hallgatók utánkövetése. FónAl (2014): i. m., 110.
} 
6. táblázat. Hogyan jutott az abszolutórium utáni első munkájához (\%).

(Diplomás Pályakövető Rendszer 2015) ${ }^{45}$

\begin{tabular}{|c|c|c|c|c|c|}
\hline & Jogá & szok & BA-vég & gzettek & \\
\hline & $\begin{array}{l}\text { Nappali } \\
\text { tagozaton } \\
\text { végzett }\end{array}$ & $\begin{array}{c}\text { Levelező } \\
\text { tagozaton } \\
\text { végzett }\end{array}$ & $\begin{array}{l}\text { Nappali } \\
\text { tagozaton } \\
\text { végzett }\end{array}$ & $\begin{array}{c}\text { Levelező } \\
\text { tagozaton } \\
\text { végzett }\end{array}$ & $\begin{array}{l}\text { Teljes } \\
\text { minta }\end{array}$ \\
\hline Álláshirdetésre jelentkezett & 48,2 & 27,6 & 40,6 & 36,7 & 42,2 \\
\hline Munkáltatónál jelentkezett & 18,4 & 24,1 & 20,3 & 20,0 & 19,7 \\
\hline Gyakorlati helyén alkalmazták & 7,9 & 0,0 & 15,9 & 0,0 & 8,2 \\
\hline Egyéb módon & 0,9 & 3,4 & 2,9 & 3,3 & 2,0 \\
\hline Tanári ajánlás révén & 2,6 & 0,0 & 1,4 & 0,0 & 1,6 \\
\hline Korábbi munkakapcsolat révén & 4,4 & 3,4 & 4,3 & 3,3 & 4,1 \\
\hline $\begin{array}{l}\text { Egyéb, személyes ismeretség } \\
\text { révén }\end{array}$ & 17,5 & 41,4 & 14,5 & 36,7 & 22,1 \\
\hline Válaszolók száma, fő & 114 & 29 & 69 & 30 & 244 \\
\hline
\end{tabular}

Egy állás elnyerésének és betöltésének formális módja (álláshirdetésre jelentkezett) inkább a nappali tagozaton és a jogász szakon jellemzőbb. Ugyancsak formális mód az, ha valaki a munkáltatónál jelentkezik, ebben kisebb eltérések tapasztalhatók. A gyakorlati hely mint lehetőség arra, hogy valaki ott is maradhasson, csak a nappalisokra és köztük is inkább az alapszakosokra jellemző (ebben a mintában legalábbis). Van azonban egy út, amely elsősorban a levelezősök előtt áll nyitva, ez pedig a személyes ismeretség, ami a munka- és személyes kapcsolatokon alapulhat (bár arra külön is rákérdeztek), ez azt jelenti, hogy bizonyos területeken a munkatapasztalattal rendelkező levelező tagozatosok vannak előnyben. Ami feltűnő, az az intézmények, a tanárok csekély szerepe a frissdiplomások elhelyezkedésében. A DE ÁJK-on végzett hallgatók körében folytatott „utánkövetés” eredményei is ezt igazolják (M2. táblázat). Más metodikával kérdeztünk rá az elhelyezkedés módjaira a 2014-es kari kutatás során (minden egyes lehetőséget egyenként kellett megítélni a kérdezettnek), ám ettöl függetlenül az alkalmazott elhelyezkedési stratégiák hasonló képet mutatnak (M3. táblázat). Az eltérés abban mutatkozik, hogy többféle formális módot jeleztek a megkérdezettek (önéletrajz, pályázat, álláshirdetés, ösztöndíj), de jelentősnek mondták az informális módozatokat is (személyes ismeretség, korábbi munkakapcsolat). Az intézményi karrieriroda és a tanári ajánlás szerepét azonban e kutatás eredményei alapján is elhanyagolhatónak mondhatjuk. Végzett hallgatónk eljutott az első állásába, kérdés, milyen jogi, igazgatási szakmában, intézményben helyezkedett el, és ez mennyiben felel meg a korábbi elvárásainak és jövőképének. Ennek megbecsüléséhez először azt vizsgáljuk meg, hogy országosan a jogi végzettségüek milyen területeken és intézményekben dolgoznak.

45 Forrás: Diplomás Pályakövető Rendszer 2015, frissdiplomások adatbázis. 


\subsection{A jogi végzettségüek és a jogászi szakmák létszámának változásai}

A jogi végzettségüek számáról és belső, szakmai megoszlásáról a népszámlálások és különböző munkaügyi statisztikák, valamint az igazságügyi hivatások esetében az országgyűlési beszámolók és az ügyvédi kamara statisztikái adnak képet. Pontos adatok elsősorban a „hivatásrendeknek” is nevezett klasszikus jogi pályákról állnak rendelkezésre, a közigazgatásban, a gazdaságban vagy más területeken dolgozó jogászokról kevésbé.

Szabó Miklós egy 2005-ös tanulmányában becsülte meg a jogi végzettségűek foglalkozás szerinti megoszlását, több adatbázis felhasználásával. ${ }^{46}$

7. táblázat. Az aktív, jogtudományi vagy igazgatási felsőfokú végzettséggel rendelkezők foglalkozás szerinti megoszlása kerekítve ${ }^{47}$

\begin{tabular}{|l|c|c|c|}
\hline & 1930 & $\mathbf{1 9 8 0}$ & $\mathbf{2 0 0 1}$ \\
\hline Igazságszolgáltatás & 8000 & 5000 & 11489 \\
\hline Igazgatás-irányítás & 4000 & 3700 & 4500 \\
\hline Jogtanácsos & 2000 & 4200 & 2300 \\
\hline Gazdaságban nem jogász & 3000 & 4300 & 12000 \\
\hline Humán szféra & 2000 & 2200 & 5000 \\
\hline Összesen & 19000 & 19400 & 35289 \\
\hline
\end{tabular}

Szabó számításai szerint a jogtudományi és igazgatási felsőfokú végzettségűek esetében az igazságszolgáltatási és a gazdaságban nem jogász munkakörben dolgozók jelentették a legnagyobb csoportot a 2000-es évek elején. Annak megítélése, hogy a jogi végzettségüek milyen területeken és milyen jogi pályákon dolgoznak, nagyon nehéz, ez alól az igazságszolgáltatási hivatások jelentenek kivételt. ${ }^{48}$

A népszámlálásoknak a jogi végzettségűekre vonatkozó adatait foglalkozási főcsoportonként és nemzetgazdasági áganként elemezve lehet megközelítően pontos adatokat közölni a jogi végzettségűek megoszlásáról. ${ }^{49}$ 2011-ben a gazdasági aktivitás szerinti adatbázis elemszáma 54625 fő, ami csaknem megfelel a 2011-es népszámlálási adatnak (55 782 fő). A TEÁOR-kódok alapján létrehozott adatbázisokba a foglalkoztatottak kerültek, 41857 fö, ami ugyancsak közel áll a népszámlálási „foglalkoztatottak” adatához (42 611). ${ }^{50}$

46 Szabó Miklós: A jogászképzés társadalmi funkciójáról - húsz év múlva. In: Szabadfalvi József (szerk.): Amabalissimus. A legszeretetreméltóbbak egyike. Loss Sándor Emlékkönyv. Debreceni Egyetem Állam- és Jogtudományi Kar, Debrecen, 2005, 307-327.

47 Szabó: i. m., 316.

48 A bírókról az Országos Bírósági Hivatal elnökének Országgyülési beszámolója, az ügyészekről $A$ legfőbb ügyész országgyülési beszámolója, az ügyvédekről a Magyar Ügyvédi Kamara adatbázisa, a közjegyzőkről a Közjegyzők országos listája alapján tájékozódhatunk a pontos adatokról.

49 FónAl Mihály: A jogászok szociológiai jellemzői: létszám, foglalkozás, kor és nem szerint. In: Jakab AndrásGajduschek György (szerk.): A magyar jogrendszer állapota. MTA Társadalomtudományi Kutatóközpont Jogtudományi Intézet, Budapest, 2016, 940-962.

50 Fónal (2016): i. m., 957. 
A nemzetgazdasági ágazatok szerinti elemzés alapján az igazságszolgáltatási területeken a teljes állásban dolgozók száma 15731 fő volt, a fogalmazókkal, jelöltekkel együtt 19720 fö.

A jogi végzettségủek száma a közigazgatásban 18 587, a gazdaságban és a nem humán szolgáltatásokban 5366, a humán szolgáltatásokban 2215 fő volt. Az igazságszolgáltatási és más területeken mintegy 42 ezer föt regisztrálhatunk, hozzátéve, hogy a statisztikai adatfelvétel módja miatt az igazságszolgáltatási, klasszikus jogászi hivatásokon túl nehéz megbízható becslést megfogalmazni a különböző jogászi szakmákban dolgozók számát illetően. A foglalkoztatott jogászok legnagyobb hányada a közigazgatásban található (44,4\%), őket az igazságszolgáltatási hivatások követik (37,5\%), a többi területen dolgozó jogászok aránya sokkal kisebb. Az igazságszolgáltatási, klasszikus jogászi professziók között az ügyvédeké a legnagyobb létszámú, az összes (foglalkoztatott) jogász 25,5\%-a tartozik közéjük. Az Országos Bírósági Hivatal elnökének beszámolója alapján 2012-ben 2782 bíró, 794 bírósági titkár és 359 fogalmazó dolgozott a bíróságokon. A legföbb ügyész országgyűlési beszámolója alapján 2012-ben 1809 főállású ügyész és 497 alügyész és fogalmazó állt alkalmazásban. A Magyar Ügyvédi Kamara összesített létszámadatai szerint ugyancsak 2012-ben 12447 ügyvéd dolgozott az országban (ebböl aktív volt 10 608), és 2392 ügyvédjelöltet regisztráltak. A Közjegyzők országos listája 315 közjegyzőt foglalt magába ebben az évben. ${ }^{51}$

Összefoglalva: a végzett joghallgatóknak leginkább arra van esélye, hogy a közigazgatásban dolgozzanak vagy a klasszikus jogászi hivatásrendek közül ügyvédként folytassanak praxist. A továbbiakban összevetjük ezeket az adatokat a frissdiplomásokra vonatkozó kutatási eredményekkel.

\subsection{Az elhelyezkedés területei jogi és igazgatási pályák és a munkáltatók szerint}

A jogi karok frissdiplomásainak foglalkozások szerinti megoszlása választ ad arra a kérdésre, hogy van-e eltérés az ideálisnak tekintett, magas státuszú és presztízsü pályák, munkahelyek és a tényleges állapot között. Hangsúlyozni kell, hogy a jogi kari hallgatók elvárásaiban, jövőképében, anticipációiban eleve egy ambivalens kép van arról, amit elképzelnek, és ami reális (lásd erről a 3.2. fejezetet). Az elhelyezkedés területeinek az elemzése előtt lássuk azt, hogy a megkeresés időpontjában a frissdiplomásoknak milyen volt a munkaerőpiaci részvétele (8. táblázat). 
8. táblázat. Munkaeröpiaci részvétel (\%). (Diplomás Pályakövető Rendszer 2015) ${ }^{52}$

\begin{tabular}{|l|c|c|c|}
\hline & Jogászok & BA-végzettek & Teljes minta \\
\hline Jelenleg (is) dolgozik & 90,5 & 94,1 & 92,3 \\
\hline Sose dolgozott & 2,8 & 1,1 & 2,0 \\
\hline $\begin{array}{l}\text { Most nem dolgozik, de már } \\
\text { volt munkahelye }\end{array}$ & 6,7 & 4,8 & 5,7 \\
\hline Összesen & 100,0 & 100,0 & 100,0 \\
\hline Válaszolók száma, fö & 359 & 356 & 715 \\
\hline
\end{tabular}

A diplomások, különösen a jogászok „tömeges” munkanélküliségére ${ }^{53}$ vonatkozó állításokat nem igazolják a megkérdezettek válaszai, hisz akik a megkérdezéskor nem dolgoztak, azoknak is volt korábban állása. Lássuk a végzettek munkahelytípusát (9. táblázat).

9. táblázat. A végzettek munkahelytípusa (milyen jogászi, igazgatási szakmában dolgozik). (Diplomás kutatás 2010)54

\begin{tabular}{|l|c|c|c|c|}
\hline & \multicolumn{2}{|c|}{ Igazgatásszervezők } & \multicolumn{2}{c|}{ Jogászok } \\
\hline & Elemszám & Százalék & Elemszám & Százalék \\
\hline Egyetem, főiskola & 1 & 1,4 & 4 & 1,6 \\
\hline Bíróság & 0 & 0,0 & 4 & 1,6 \\
\hline Ügyészség & 0 & 0,0 & 3 & 1,2 \\
\hline Ügyvédi iroda & 0 & 0,0 & 57 & 23,3 \\
\hline Államigazgatás & 24 & 34,3 & 77 & 31,4 \\
\hline Önkormányzati igazgatás & 25 & 35,7 & 33 & 13,5 \\
\hline Gazdálkodó szervezetek & 7 & 10,0 & 41 & 16,7 \\
\hline Civil szervezetek & 1 & 1,0 & 3 & 1,2 \\
\hline Egyéb & 5 & 7,1 & 22 & 9,0 \\
\hline Elemszám & 70 & 100,0 & 245 & 100,0 \\
\hline
\end{tabular}

52 Forrás: Diplomás Pályakövető Rendszer 2015, frissdiplomások adatbázis.

53 Ezek a megállapítások a közbeszédre jellemzőek, a „jogásztúlképzés” toposzával függnek össze, komoly tudományos publikációk és kutatások nem igazolják, sőt a DPR-adatok kifejezetten alacsony jogász munkanélküliséget jeleznek.

54 Forrás: Diplomás kutatás 2010. Educatio Nonprofit Kft.; FónAl (2014): i. m., 120. 
A jogi végzettségü frissdiplomások 54,9\%-a dolgozott a 2010-es országos DPRadatfelvétel idején a tágabban vett közigazgatásban, ami magasabb a 2011-es népszámlálás megfelelő adatainál, azaz az egyetem befejezése után a legnagyobb munkáltató a közigazgatás. A pályakezdő jogászok között az ügyvédi irodákban dolgozók aránya nagyon közel áll a 2011-es népszámlálás alapján számított adatokhoz, és hasonló a helyzet a többi klasszikus hivatásrend esetében is. A gazdálkodó szervezeteknél elhelyezkedő jogvégzettek aránya is közel áll a népszámlálási adatokhoz. Ami szembetűnő, a civil szervezetek csekély hatást gyakorolnak a végzett jogászokra. Az igazgatásszervezők leginkább a tágabban vett közigazgatásban helyezkednek el, ami megfelel a végzettségüknek (lásd a 12. és a 13. táblázatot).

Fontos hangsúlyozni, hogy a népszámlálási adatbázisból a kongruenciaeljárással ${ }^{55}$ főcsoportonként és nemzetgazdasági ágazatonként számított adatok is sok bizonytalanságot tartalmaznak, leginkább a klasszikus hivatásrendekre vannak pontos adataink az országgyűlési beszámolók és a Magyar Ügyvédi Kamara adatnyilvántartása miatt. A 2015-ös DPR adatbázisa sem reprezentatív mintavételen alapuló kutatás eredménye (bár az adatokat súlyozták), ráadásul a 9. táblázatban szereplő szakmákat a megfelelő képzési területi adatbázisból válogattuk le. Mindez óvatosságra int az eredmények általánosíthatóságát illetően. Ami biztosan megfogalmazható, az az, hogy a jogi végzettségüek az egyetem után leginkább a közigazgatásban ${ }^{56}$ és az ügyvédi irodákban helyezkednek el. Ezt igazolják a DE ÁJK-on 2001 és 2008 között a végzett hallgatók körében folytatott utánkövetés eredményei is (M4. táblázat), amely arra is rámutat, hogy a tagozatok között is jelentős különbség érvényesül, a nappali tagozaton végzettek magasabb arányban kerülnek a közigazgatásba, míg a levelezőn végzettek esetében magasabb a nem jogi területen és a rendőrségnél dolgozók aránya. Ezek a különbségek tartósnak tünnek, évtizedes tendenciaként érvényesülnek az eltérő tagozaton végzettek között, ezt mutatják az 1973-as jogászkutatás eredményei is. ${ }^{57}$ A 2015-ös DPR-adatfelvétel alapján jogi végzettségủek esetében körülbelül fele-fele a köztisztviselök, állami, önkormányzati vállalatok alkalmazottainak és a „más helyen” dolgozóknak az aránya (10. táblázat). A tágabban vett „köztisztviselök és közalkalmazottak” aránya a 2015-ös DPR-felmérés alapján alacsonyabb, mint a 2010-es DPR-adatfelvételé vagy a népszámlálási adatbázisé ettől függetlenül a „köztisztviselöi-közalkalmazotti” státusz meghatározó a jogi végzettségüek körében, és még ennél is magasabb az igazgatásszervezők esetében.

55 Lakatos Miklós (szerk.): A képzettség és a foglalkozás megfelelésének (kongruenciájának) elemzése a 2011. évi népszámlálás adatainak felhasználásával. KSH, Budapest, 2015; FónAl (2016): i. m., 940-962.

56 A kérdést Gajduschek elemzi több tanulmányában is. A kilencvenes, kétezres években 100-110 ezer fö dolgozott köztisztviselöként, akiknek 52 százaléka volt felsőfokú végzettségü; 2004-ben a felsőfokú végzettségủek $13 \%$-a volt jogi végzettségủ az önkormányzati igazgatásban, és ugyancsak 13\%-a az államigazgatásban. Lásd GAJduscheK György: Közszolgálat. A magyar közigazgatás személyi állománya és személyzeti rendszere az empirikus adatok tükrében. KSzK-MKI, Budapest, 2008. Továbbá HAZAFI Zoltán: Közszolgálati jogunk a változó nemzetközi és hazai térben. (De lege lata, de lege ferenda). PhD-értekezés. Pécsi Tudományegyetem, Pécs, 2009.

57 Léderer Pál (szerk.): A jogászság társadalmi helyzete és szakmai életútja. (Kutatási beszámoló) Oktatási Minisztérium, Budapest, 1977. 
10. táblázat. Közalkalmazott-e (\%). (Diplomás Pályakövető Rendszer 2015) ${ }^{58}$

\begin{tabular}{|l|c|c|c|}
\hline & Jogászok & BA-végzettek & Teljes minta \\
\hline $\begin{array}{l}\text { Köztisztviselö, közalkalmazott, } \\
\text { kormánytisztviselő }\end{array}$ & 46,0 & 71,2 & 59,0 \\
\hline $\begin{array}{l}\text { Állami, önkormányzati vállalat } \\
\text { alkalmazottja }\end{array}$ & 2,5 & 5,7 & 4,2 \\
\hline Más helyen dolgozik & 51,4 & 23,1 & 36,9 \\
\hline Összesen & 100,0 & 100,0 & 100,0 \\
\hline Válaszolók száma, fö & 316 & 333 & 648 \\
\hline
\end{tabular}

$p=0,000$

A köztisztviselői, közalkalmazotti munkahelyek magas aránya részben a munkaerőpiaci kínálattal függ össze, azzal, hogy hol „keletkeznek” állások a jogi és igazgatási végzettségüek számára. Emellett fontosnak tünik az is, hogy az érintettek számára fontos az állás biztonsága, kiszámíthatósága (lásd az 5. táblázatot és a következő fejezetet). A biztonságot és a kiszámíthatóságot növeli az is, hogy a betöltött álláshelyek meghatározó módon állandó jellegű és határozatlan idejű munkaviszonyt jelentenek (11. táblázat).

11. táblázat. A válaszolók fő munkaviszonya (\%).

(Diplomás Pályakövető Rendszer 2015) ${ }^{59}$

\begin{tabular}{|l|c|c|c|}
\hline & Jogászok & BA-végzettek & Teljes minta \\
\hline $\begin{array}{l}\text { Állandó jellegű és határozatlan } \\
\text { idejű }\end{array}$ & 89,5 & 85,3 & 87,4 \\
\hline Határozott idejű & 9,8 & 14,4 & 12,2 \\
\hline Alkalmi vagy megbízás jellegű & 0,6 & 0,3 & 0,5 \\
\hline Összesen & 100,0 & 100,0 & 100,0 \\
\hline Válaszolók száma, fő & 315 & 334 & 649 \\
\hline
\end{tabular}

4.6. A végzett munkával kapcsolatos vélemények és elégedettség, végzettség és a munka illeszkedése

A végzett munkával való elégedettség több dologgal is összefügg, így például azzal, hogy milyennek látják az érintettek a pályaválasztásukat, mennyire felel meg a munka a korábbi elvárásaiknak, és hogy milyen a viszonya a végzettségnek (kép-

58 Forrás: Diplomás Pályakövető Rendszer 2015, frissdiplomások adatbázis.

59 Forrás: Diplomás Pályakövető Rendszer 2015, frissdiplomások adatbázis. 
zettségnek) és a tényleges munkának. Az elégedettséget így a pályáról kialakult kép (az ideálkép) és a tényleges munka (a valóság) viszonya is alakítja. A DE ÁJK-on végzett jogászok esetében a korai pályaválasztással és a választással való elégedettség mellett a távlati célok és a célok megvalósításának a lehetősége az, ami alakítja a véleményüket, azt, hogy miért felel meg a munkájuk az elképzeléseiknek (M5. táblázat). Úgy tủnik, a véleményeket e kérdésről a „beválás” alakítja, tehát az elégedett, aki úgy érzi, azt teheti, amit mindig is akart és ami a céljainak megfelel. Ez megerősíti azt az állításomat, mely szerint a jogi (és az igazgatási) képzésben a hallgatók fejében egyszerre van jelen a pályával, hivatással összefüggő „ideálkép”, ami a hivatás föbb vonásait és lehetőségeit jelenti, és egy kép arról, mi is várható a „valóságban”, milyen területeken lehet elhelyezkedni, és e területeknek milyen föbb jellemzői vannak. A szak, illetve a szakma választása, illetve a választás megfelelőségében jelentős eltérések vannak az aktív és a végzett hallgatók között, ezek közül a korábbi elvárásnak és a korábbi céloknak való megfelelés között szignifikáns különbség érvényesül (3. ábra).

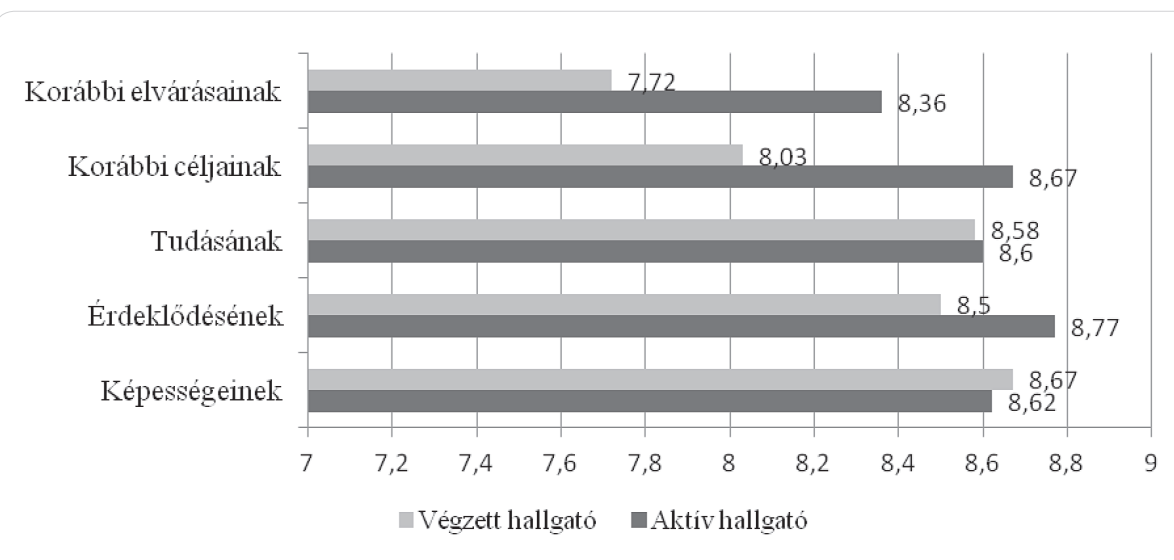

3. ábra. Megfelel-e a szak (szakma) választása Önnek a következő területeken (tízfokozatú skála). (DE ÁJK 2014) ${ }^{60}$

Úgy tủnik, a munkatapasztalatok sok szempontból „faragnak” a korábbi elvárásokban és célokban felépített ideálképből, hisz a korábbi elvárásokat jóval kevésbé érzik megvalósulni a végzett hallgatók (bár egy tízfokozatú skálán az ő értékelésük is magas). A tapasztalatok és a tényleges munka miatt a végzettek inkább gondolják azt, hogy a szakma választása kevésbé felel meg az érdeklődésüknek, ugyanakkor az aktív és a végzett hallgatók is úgy becsülik, hogy a szak, illetve a szakma választása megfelel tudásuknak és képességeiknek. Az országos DPR-vizsgálatok eredményei azt mutatják, hogy a frissdiplomások nagyon kritikusak munkájuk különböző összetevőit illetően (4. ábra).

${ }^{60}$ Forrás: DE ÁJK aktív és végzett hallgatók kutatása, 2014. Szignifikáns különbségek: korábbi elvárások $(p=0,020)$, korábbi életcél $(p=0,016)$. 


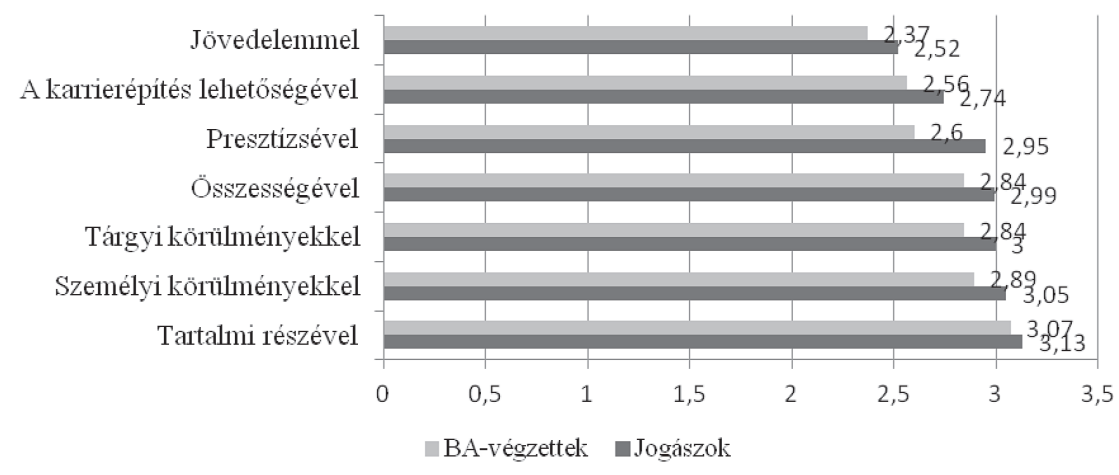

4. ábra. Mennyire elégedett a munkával kapcsolatos táblázatban szereplő összetevőkkel (négyfokozatú skálán).

(Diplomás Pályakövető Rendszer 2015) ${ }^{61}$

A 2015-ben megkérdezett fiatal jogászok, igazgatásszervezők és igazságügyi igazgatási, valamint munkaügyi szakemberek - hasonlóan az összes többi fiatal diplomáshoz - legkevésbé a jövedelmükkel, leginkább pedig a munkájuk tartalmi részével elégedettek. ${ }^{62} \mathrm{~A}$ jogászok és a BA-végzettségüek elégedettsége között a munka tartalmi részén túl minden területen szignifikáns különbség érvényesül, az alapszakokon végzettek kevésbé elégedettek a jövedelmükkel, a karrierépítés lehetőségével és a munka személyi és tárgyi körülményeivel; legnagyobb különbség a munka presztízsének a megítélésében mutatkozik. A végzett munka összetevőivel való elégedettség azt mutatja, hogy a diploma (abszolutórium) megszerzése után egy-három évvel (ekkor keresik meg a frissdiplomásokat) a fiatal szakemberek a munkába való beilleszkedés sok szempontból sokkoló fázisában vannak, amit a szakirodalom „kapunyitási pániknak" hív. ${ }^{63}$ Ez azt eredményezi, hogy - ahogy láttuk - magát a szak- és szakmaválasztást a pályakezdés során átgondolt döntésnek látják a frissdiplomások, ugyanakkor magával a konkrét munkával, amit végeznek, kevésbé elégedettek. A karon 2001 óta folyó alumni- és elsőéves adatfelvételek tapasztalatai alapján vettük át a 2014-es kari „frissdiplomás” kutatásunkba a szak, illetve a szakma helyzetét jellemző kérdésblokkot, ami sok szempontból megfelel az országos DPR-kutatás hasonló kérdésblokkjának. A kari kutatás során nem a munka összetevőivel való elégedettséget mértük, hanem a szak, a szakma egy általánosabb megítélését, azaz nem azt, hogy a megkérdezett hogyan éli meg a saját helyzetét, hanem azt, hogy hova sorolja az adott hivatást, és milyennek ítéli meg annak néhány területét, azaz más szakmákhoz, hivatásokhoz képest is elhelyezi a saját szakmáját (5. ábra).

61 Forrás: Diplomás Pályakövető Rendszer 2015, frissdiplomások adatbázis.

62 Garai Orsolya-Horváth Tamás-Kiss László-Szép Lilla-Veroszta Zsuzsanna (szerk.): Frissdiplomások 2010. Educatio Társadalmi Szolgáltató Nonprofit Kft., Budapest, 2010.

63 LEIST BALOGH Brigitta-JÁmBORI Szilvia: A kapunyitási pánik vizsgálata a megküzdési módok és a szorongás függvényében. Alkalmazott Pszichológia, 2016/2, 62-90. 


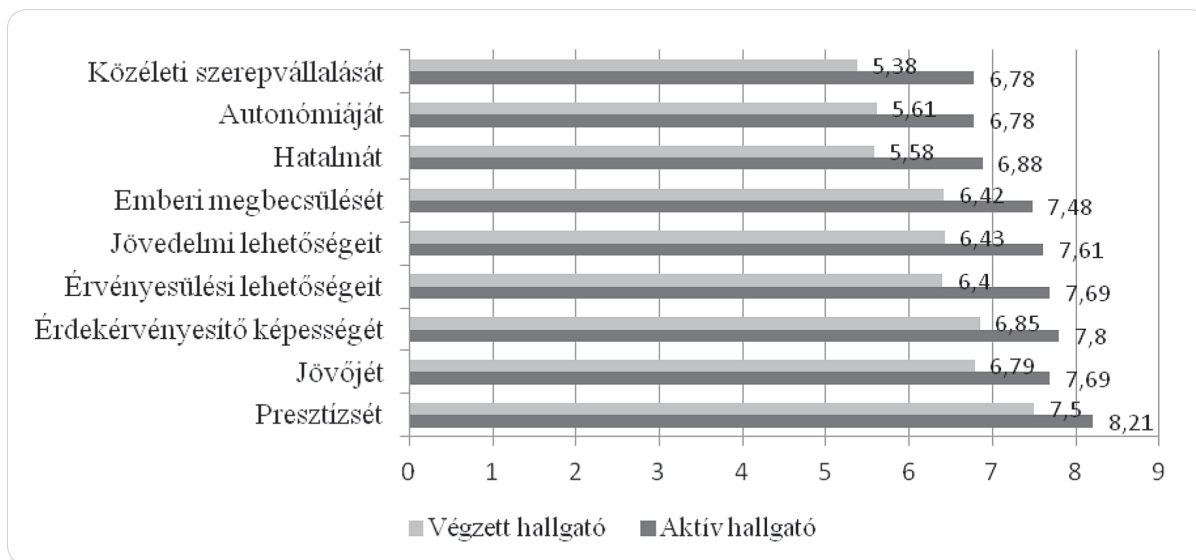

5. ábra. Milyennek látja szakja, szakmája esetében a következő tényezőket (tízfokozatú skálán). (DE ÁJK 2014) ${ }^{64}$

A kar aktív és végzett hallgatói rangsorai között minden állítás esetében szignifikáns különbségek vannak. Az aktív hallgatók a szak/szakma helyzetét minden lehetséges területen sokkal kedvezöbbnek látják, mint a végzett hallgatók. Ahogy láttuk, a két csoport közötti különbségek más területen is érvényesülnek, az aktív hallgatók jobbnak látják, sok szempontból ideálisabb helyzetben látják a szakmájuk helyzetét, mint azok, akik már dolgoznak. Az aktív hallgatók saját szakmájukat magas presztízsű, jó jövedelmi pozíciójú, jó lehetőségekkel bíró, autonóm, közéleti szerepeket is lehetővé tevő szakmának látják. A végzett hallgatók sokkal kevésbé tartják magas presztízsűnek a szakmájukat, és inkább „erős közepes” jegyet adnak a jövedelmi lehetőségekre, az érdekérvényesítésre, általában a jövőbeli lehetőségekre, és „közepesre” taksálják a szakma autonómiáját, hatalmát és a közéleti szerepvállalás lehetőségeit. Az eltérő élethelyzet miatt mintha a hallgatók fejében a szakma idealizált képe élne, velük szemben a végzett szakemberek saját szakmájuk sokkal szerényebb lehetőségeiről számolnak be, az ő fejükben a tapasztalatokon nyugvó professziókép él. A saját helyzet és a választott, gyakorolt szakma, hivatás megítélését jelentősen alakítja, hogy mennyire illeszkedik a végzettség tartalma és szintje a tényleges munkához (12., 13. táblázat).

64 Forrás: DE ÁJK aktív és végzett hallgatók kutatása, 2014. 
12. táblázat. Milyen szakterületen végzett tanulmányok felelnek meg jelenlegi munkájának (\%). (Diplomás Pályakövető Rendszer 2015)

\begin{tabular}{|l|c|c|c|}
\hline & Jogászok & BA-végzettek & Teljes minta \\
\hline $\begin{array}{l}\text { A saját és a kapcsolódó } \\
\text { szakterületek }\end{array}$ & 52,1 & 68,8 & 60,7 \\
\hline $\begin{array}{l}\text { Csak a saját végzettség } \\
\text { szakterülete }\end{array}$ & 40,6 & 11,2 & 25,5 \\
\hline Egy egészen más szakterület & 5,8 & 17,0 & 11,5 \\
\hline Bármilyen szakterület & 1,6 & 3,0 & 2,3 \\
\hline Összesen & 100,0 & 100,0 & 100,0 \\
\hline Válaszolók száma & 313 & 330 & 643 \\
\hline
\end{tabular}

A fiatal jogászoknak a meghatározó többsége (92,7\%-a) a saját és a kapcsolódó szakterületeken végzett tanulmányokat nevezte meg, mint ami szükséges a munkájához, azaz a végzettség és a munka illeszkedése nagyon magas, ami azt mutatja, hogy a friss diplomás jogászok jogi területeken helyezkednek el. A BA-szakokat végzettek esetében már sokkal magasabb azoknak az aránya, akiknek nem illeszkedik a képzettsége a munkájához (a két diplomás csoport között e területen és a képzettség szintjét tekintve is szignifikáns különbség van). Némileg módosul a kép, ha a képzettség szintjét is megvizsgáljuk, ebben a kontextusban a jogi végzettségüeknek is csaknem az egyötöde arról számol be, hogy a munkájához nem szükséges egyetemi vagy felsőfokú végzettség. A BA-szakokon végzetteknél sem magasabb a hasonló válaszok aránya, esetükben viszonylag magas azoknak az aránya, akik szerint egyetemi szintű végzettség volna szükséges a munkájukhoz. ${ }^{66}$ Mivel a képzettség tartalma és szintje, különösen a jogász végzettségüek között, jelentős mértékben illeszkedik a tényleges munkához, a munkával kapcsolatos véleményüket és attitüdjeiket a munka tartalma és az intézményes hatások alakíthatják, ezek következtében látják viszonylag kedvezőtlennek a munka egyes összetevőit.

13. táblázat. Milyen szintű képzettség felel meg legjobban jelenlegi munkájának (\%).

(Diplomás Pályakövető Rendszer 2015) ${ }^{67}$

\begin{tabular}{|l|c|c|c|}
\hline & Jogászok & BA-végzettek & Teljes minta \\
\hline Egyetemi/MA & 82,6 & 14,1 & 47,5 \\
\hline Főiskolai/BA & 9,3 & 65,4 & 38,1 \\
\hline Nem igényel felsőfokút & 4,5 & 19,6 & 12,2 \\
\hline
\end{tabular}

65 Forrás: Diplomás Pályakövető Rendszer 2015, frissdiplomások adatbázis.

66 FónAı Mihály-Kotsıs Ágnes-Szücs Edit: A munkaerö-piaci sikeresség vizsgálata. Felsőoktatási Műhely, 2014/8, 91-106.

67 Forrás: Diplomás Pályakövető Rendszer 2015, frissdiplomások adatbázis. 


\begin{tabular}{|l|c|c|c|}
\hline & Jogászok & BA-végzettek & Teljes minta \\
\hline Egyéb posztgraduális & 2,9 & 0,9 & 1,9 \\
\hline PhD & 0,6 & 0,0 & 0,3 \\
\hline Összesen & 100,0 & 100,0 & 100,0 \\
\hline Válaszolók száma & 311 & 327 & 638 \\
\hline
\end{tabular}

\section{5. Összegzés}

A tanulmányban elemzett empirikus kutatások eredményei alapján a hipotézisekre reflektálva a következők fogalmazhatók meg. Az első hipotézis, mely a szakmai fejlődési szakaszok harmadik fázisára jellemző kompromisszumra utal, a vágyak és a lehetőségek ismeretében igazolódott, ami esetünkben az „ideálkép és a valóság” közötti kompromisszumot jelenti; sok szempontból ez az elemzett kutatások legfontosabb konzekvenciája.

A második hipotézis a pályaválasztásra ható személyek és intézményi hatások szerepének változásaira utal, feltételezve a család szerepének csökkenését - ez a hipotézis is igazolódott. A nappali tagozaton tanulók esetében arról van szó, hogy a hallgatók önállónak látják döntéseiket, melyre elsősorban magának a választott hivatásnak (és a felsőoktatásnak), az azzal kapcsolatosan kialakított elvárásoknak van meghatározó szerepe. A levelező tagozatosok esetében ehhez járul még az eltérő élethelyzet hatása, hisz esetükben az egyetem, és szakválasztást az is alakítja, hogy a munkájuk és az előmenetelük miatt is fontos számukra a diploma.

A harmadik hipotézis a ,jövőre vonatkozó elvárásokkal” kapcsolatos, azt vártam, hogy a „várakozásoknak” vannak tartós összetevői. Ez részben arra vonatkozik, hogy milyen jogi területen, milyen jogi szakmákat müvelnének a hallgatók és a frissdiplomások, e mögött húzódnak meg az egyes jogi, igazgatási pályákhoz kapcsolódó elvárások, attitüdök és sztereotípiák. Ha a kutatásoknak a jövőbeli tervekre, elvárásokra vonatkozó eredményeit vesszük figyelembe, azt láthatjuk, hogy azok ugyancsak az „ideálkép-valóság” kontextusába illeszthetők, azaz a hallgatók és a frissdiplomások elvárásai között egyszerre hatnak például presztízs- és karrierszempontok (ami a jogi és igazgatási területekre és szakmákra, hivatásokra vonatkozik), és a biztonság, a kiszámíthatóság iránti elvárás. Ez azt jelenti, hogy bár a hipotézis igazolódott, maguk az elvárások, a „várakozások” azok, melyek gyakran ellentmondásosak.

A negyedik és az ötödik hipotézis a magas státuszú professziók presztízsére vonatkozik, azaz arra, hogy a pályaválasztást és a jövőre vonatkozó elvárásokat a presztízsszempontok határozzák meg, és ebben eltérés van a joghallgatók és a jogi karok alapszakos hallgatói között. A vizsgált kutatások eredményei azt mutatják, hogy a negyedik hipotézis csak részben igazolódik, a joghallgatók választásait az egyetem, és szakválasztástól a konkrét munkahely választásáig jelentős mértékben valóban a presztízsszempontok mozgatják. Ugyanakkor, ha a jelenséget az „ideálkép-valóság" kontextusba helyezzük, azt látjuk, hogy a presztízst nagyon fontosnak 
tartó joghallgatók és frissdiplomás jogászok a konkrét döntéseikben más szempontokat is figyelembe vesznek. Így például, bár a klasszikus igazságügyi hivatásokat, hivatásrendeket tartják a legnagyobb presztízsűnek a jogi hivatások között, a tényleges preferenciák és döntések esetében e hivatásrendek vonzása csekély, míg az alacsonyabbra taksált közigazgatásé sokkal jelentősebb. Ezt az ellentmondást, mely a jogászok énképének egyik meghatározó ellentmondásának tűnik, ugyancsak az „ideálkép-valóság” kontextusában lehet feloldani: a hivatásrendek a vonzóak, de elhelyezkedni reálisan a kevésbé vonzó területeken lehet, ez alól kivételt az ügyvédi professzió jelent, ami vonzó is és reális döntésnek is tủnik a joghallgatók számára. A jogi karok alapszakos hallgatóinak a professzióképére vonatkozó hipotézis igazolódott, hisz esetükben a presztízsnek mint szempontnak a hatása kisebb a joghallgatókhoz és a végzett jogászokhoz képest.

A tanulmányban feldolgozott és elemzett kutatások eredményei alapján végül is legfőbb megállapításunk az lehet, hogy a joghallgatók (és a jogi karok más szakos hallgatói) egyszerre gondolkodnak a szakmájukra, hivatásukra jellemzőnek vélt és tartott „ideálkép” és a „valóság” alapján szakmájuk, hivatásuk helyzetéröl. Ez megfelel a fejlődéselvet hangsúlyozó elméletek (például Ginzberg) állításainak a „kompromisszumot" illetően.

Az „ideálkép” segít a pályaválasztásban és segít a szakmai szocializáció során, vonzó mintákat és értékeket közvetítve. A „valóság” pedig abban segít, hogy a végzés után a fiatal szakemberek számára a „kapunyitási pánik” elviselhető legyen, ne sokkolja őket az ideálistól eltérő helyzet. Ez a kettősség érhető tetten a hallgatók és a végzettek elvárásaiban, választásaiban, rangsoraiban és véleményében. Különbségek a szakok és a tagozatok alapján találhatók, a jogász szak magas presztízse jelentős mértékben alakítja a hallgatók és frissdiplomások énképét és elvárásait is, ugyanakkor az tapasztalható, hogy az aktív hallgatókhoz képest a fiatal diplomások professzióképe sokkal földhözragadtabb, a hallgatókhoz képest kritikus és kevésbé idealizált. Hasonló a helyzet a tagozatok között is, a levelező tagozatosok és az e tagozaton végzettek sokkal kevésbé „idealizálják” szakjukat és szakmájukat, hivatásukat. A szakok és a tagozatok közötti különbségek a pályaszocializációs, felsöoktatási szakmai szocializációs, anticipatív szocializációs elméletek (Astin, Daheim, Musgrave) állitásaival is magyarázhatók.

\section{Abstract}

The present study examines how the image of profession changes for law students in the different stages of their connection with the profession. It assumes that at the beginning of their studies, law students have an idealised image of their chosen study program and the profession based on it. This image changes during the years of studying, and especially after graduation, it is shifted by work experience and by the factual state of the profession. Students of the Faculty of Law, especially law students identify themselves based on the internal and external elements of a prestigious profession, which was established hundreds of years ago. Due to their early career choice, their professional socialization during the first years at the 
university creates the ideal image of the legal profession, which they strongly relate to. The relationship of this ideal image to reality, and how different it is from the real situation of various professional groups of the legal profession is an important question. The present study answers this question based on the results of multiple empirical researches.

\section{Mellékletek}

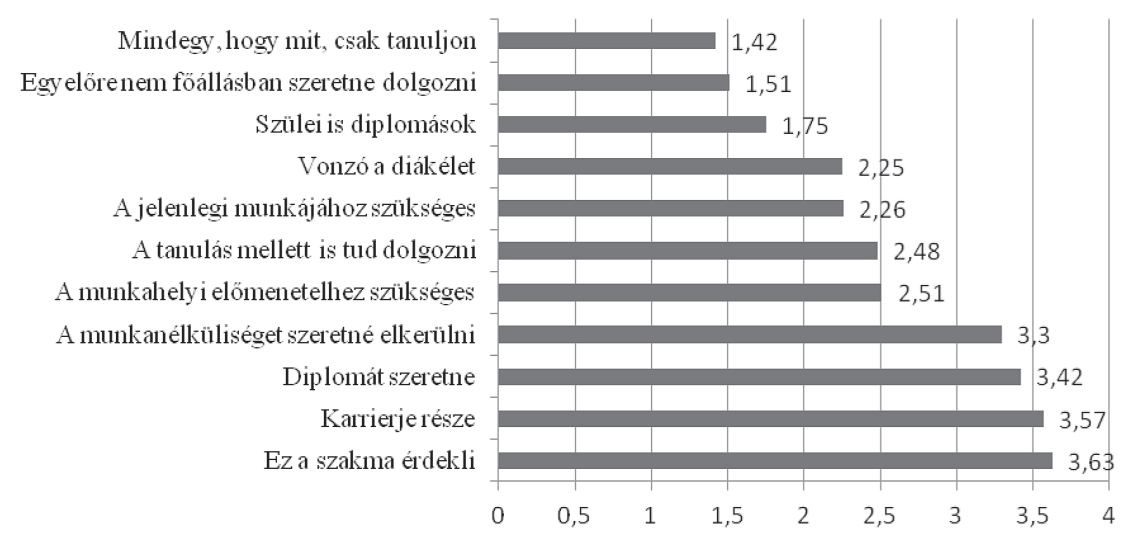

M1. ábra. A következő tényezők mennyire befolyásolták, hogy egyetemre jelentkezzen (négyfokozatú skálán). (DE ÁJK 2014) ${ }^{68}$

M1. táblázat. Tervek az egyetem befejezése után (az összes válasz százalékában). (DE ÁJK „gólya”-kutatás, 2006-2008 első szakasz) ${ }^{69}$

\begin{tabular}{|l|c|c|c|c|c|}
\hline \multirow{2}{*}{} & \multicolumn{2}{|c|}{ Igazgatásszervező } & \multicolumn{2}{c|}{ Jogász } & \multirow{2}{*}{$\begin{array}{c}\text { Teljes } \\
\text { minta }\end{array}$} \\
\cline { 2 - 5 } & $\begin{array}{c}\text { Nappali } \\
\text { tagozat }\end{array}$ & $\begin{array}{c}\text { Levelező } \\
\text { tagozat }\end{array}$ & $\begin{array}{c}\text { Nappali } \\
\text { tagozat }\end{array}$ & $\begin{array}{c}\text { Levelező } \\
\text { tagozat }\end{array}$ & \\
\hline A szakmában elhelyezkedni & 24,9 & 24,4 & 23,4 & 8,2 & 21,8 \\
\hline Újabb diploma & 35,2 & 15,3 & 7,9 & 4,1 & 15,7 \\
\hline Közigazgatás & 11,9 & 16,8 & 3,3 & 2,7 & 8,1 \\
\hline Karrier, befolyás & 1,1 & 19,8 & 4,7 & 10,2 & 7,8 \\
\hline Ügyvéd & 0,0 & 0,0 & 11,7 & 16,2 & 7,3 \\
\hline Jól fizető állás & 10,2 & 6,9 & 2,8 & 3,4 & 4,2 \\
\hline
\end{tabular}

68 Forrás: DE ÁJK aktív és végzett hallgatók kutatása, 2014.

69 Forrás: FónAl (2014): i. m., 106. 


\begin{tabular}{|c|c|c|c|c|c|}
\hline & \multicolumn{2}{|c|}{ Igazgatásszervező } & \multicolumn{2}{|c|}{ Jogász } & \multirow{2}{*}{$\begin{array}{l}\text { Teljes } \\
\text { minta }\end{array}$} \\
\hline & $\begin{array}{l}\text { Nappali } \\
\text { tagozat }\end{array}$ & $\begin{array}{l}\text { Levelező } \\
\text { tagozat }\end{array}$ & $\begin{array}{l}\text { Nappali } \\
\text { tagozat }\end{array}$ & $\begin{array}{l}\text { Levelező } \\
\text { tagozat }\end{array}$ & \\
\hline EU-állás & 2,8 & 0,0 & 8,4 & 3,4 & 4,1 \\
\hline Külföld & 1,4 & 0,0 & 7,7 & 2,0 & 3,4 \\
\hline Munkahely megtartása & 0,0 & 4,6 & 0,0 & 10,6 & 3,3 \\
\hline Szakosodás & 2,2 & 0,8 & 2,8 & 6,8 & 3,3 \\
\hline Bármilyen jogi terület & 0,0 & 0,0 & 6,5 & 6,4 & 3,3 \\
\hline Biztos állás & 4,5 & 1,5 & 3,3 & 0,0 & 2,5 \\
\hline Munkahelyváltás & 0,6 & 3,8 & 0,0 & 4,7 & 1,9 \\
\hline Ügyész & 0,0 & 0,0 & 2,8 & 2,7 & 1,5 \\
\hline Családi élet & 2,3 & 0,0 & 1,4 & 1,4 & 1,3 \\
\hline Jogtanácsos & 0,0 & 0,0 & 1,4 & 3,4 & 1,2 \\
\hline Jegyző & 2,3 & 1,5 & 0,5 & 0,7 & 1,2 \\
\hline Rendőrség & 0,0 & 1,5 & 0,5 & 1,4 & 0,7 \\
\hline Saját cég & 0,6 & 0,0 & 0,5 & 2,0 & 0,7 \\
\hline Közjegyző & 0,0 & 0,0 & 1,9 & 0,7 & 0,7 \\
\hline Adótanácsadó & 0,0 & 0,0 & 0,0 & 0,7 & 0,1 \\
\hline $\begin{array}{l}\text { Családi vállalkozás, } \\
\text { praxis átvétele }\end{array}$ & 0,0 & 0,0 & 1,9 & 0,0 & 0,6 \\
\hline Válaszhiány & - & 3,1 & - & 4,2 & 2.3 \\
\hline Összesen & 100,0 & 100,0 & 100,0 & 100,0 & 100,0 \\
\hline
\end{tabular}

$(\mathrm{N}=669)$

M2. táblázat. Milyen módon került jelenlegi munkahelyére?

(DE ÁJK 2001-2008, utánkövetés) ${ }^{70}$

\begin{tabular}{|l|c|c|c|}
\hline \multirow{2}{*}{} & \multicolumn{2}{|c|}{ Tagozat } & \multirow{2}{*}{ Teljes minta } \\
\cline { 2 - 3 } & Nappali & Levelező & \\
\hline Pályázattal & 55,3 & 45,0 & 52,4 \\
\hline Ismeretséggel & 23,6 & 22,9 & 23,4 \\
\hline Pályázattal, ismeretség útján & 7,4 & 1,8 & 5,9 \\
\hline Felkérték, megkeresték & 4,2 & 7,3 & 5,1 \\
\hline
\end{tabular}

70 Forrás: FónAl (2014): i. m., 111. 


\begin{tabular}{|l|c|c|c|}
\hline \multirow{2}{*}{} & \multicolumn{2}{|c|}{ Tagozat } & \multirow{2}{*}{ Teljes minta } \\
\cline { 2 - 3 } & Nappali & Levelező & \\
\hline A szülök, rokonok praxisában dolgozik & 3,9 & 7,3 & 4,8 \\
\hline Ösztöndíjjal & 2,5 & 6,4 & 3,6 \\
\hline Egyéb & 2,1 & 4,6 & 2,8 \\
\hline Nem válaszolt & 0,6 & 2,8 & 1,3 \\
\hline Apróhirdetés útján & 0,4 & 1,8 & 0,8 \\
\hline Összesen & 284 & 109 & 393 \\
\hline
\end{tabular}

M3. táblázat. Milyen módon került jelenlegi munkahelyére?

(Az egyes kérdésekre válaszolók \%-a) (DE ÁJK 2014) (11 $^{7}$

\begin{tabular}{|c|c|c|c|}
\hline & $\begin{array}{c}\text { Még aktív } \\
\text { hallgatója } \\
\text { a karnak }\end{array}$ & $\begin{array}{c}\text { Végzett } \\
\text { hallgatója } \\
\text { a karnak }\end{array}$ & Összesen \\
\hline Elküldte az önéletrajzát & 43,2 & 48,8 & 46,8 \\
\hline Felkérték, megkeresték & 31,1 & 41,5 & 37,8 \\
\hline Személyes ismeretség révén & 40,9 & 34,5 & 36,7 \\
\hline Pályázat útján & 22,7 & 35,4 & 31,0 \\
\hline Álláshirdetésre jelentkezett & 30,4 & 17,5 & 22,2 \\
\hline Korábbi munkakapcsolat révén & 14,0 & 22,5 & 19,5 \\
\hline Gyakorlati helyen alkalmazták & 16,3 & 10,0 & 12,2 \\
\hline Apróhirdetés útján & 7,0 & 2,6 & 4,2 \\
\hline A szülők, rokonok praxisában dolgozik & 9,3 & 0,0 & 3,3 \\
\hline Ösztöndíjjal & 2,4 & 2,6 & 2,5 \\
\hline Intézményi karrieriroda & 2,4 & 0,0 & 0,8 \\
\hline Tanári ajánlás révén & 0,0 & 1,3 & 0,8 \\
\hline
\end{tabular}

71 Forrás: DE ÁJK aktív és végzett hallgatók kutatása, 2014. 
M4. táblázat. Milyen jogi területen dolgozik? (DE ÁJK 2001-2008, utánkövetés)72

\begin{tabular}{|l|c|c|c|}
\hline \multirow{2}{*}{} & \multicolumn{2}{|c|}{ Tagozat } & \multirow{2}{*}{ Teljes minta } \\
\cline { 2 - 4 } & Nappali & Levelező & \\
\hline Állami és önkormányzati közigazgatás & 40,6 & 32,6 & 38,4 \\
\hline Ügyvédi iroda & 22,4 & 19,1 & 21,5 \\
\hline Bíróság & 7,5 & 6,7 & 7,3 \\
\hline Nem jogi terület & 5,0 & 12,4 & 7,0 \\
\hline Ügyészség & 6,2 & 4,5 & 5,8 \\
\hline Egyéb jogi terület & 5,4 & 6,7 & 5,8 \\
\hline Nem válaszolt & 5,8 & 4,5 & 5,5 \\
\hline Rendörség & 1,2 & 9,0 & 3,3 \\
\hline Piaci terület & 1,7 & 2,2 & 1,8 \\
\hline Nappalis PhD-hallgató & 2,1 & 0,0 & 1,5 \\
\hline Felsőoktatás & 1,2 & 1,1 & 1,2 \\
\hline Jelenleg nem dolgozik & 0,8 & 1,1 & 0,9 \\
\hline
\end{tabular}

M5. táblázat. Miért felel meg jelenlegi munkája az elképzeléseinek? (Az említések száma) (DE ÁJK 2001-2008, utánkövetés) ${ }^{73}$

\begin{tabular}{|l|c|c|c|}
\hline \multirow{2}{*}{} & \multicolumn{2}{|c|}{ Tagozat } & \multirow{2}{*}{ Teljes minta } \\
\cline { 2 - 4 } & Nappali & Levelező & \\
\hline Mindig ezt akarta & 50 & 8 & 58 \\
\hline Nem erre készült, de megfelel & 29 & 8 & 37 \\
\hline Távlati céljainak is megfelel & 17 & 13 & 30 \\
\hline A szakvizsga miatt & 17 & 8 & 25 \\
\hline Megfelel a személyiségének & 17 & 7 & 24 \\
\hline Meg tudja valósítani céljait & 11 & 5 & 16 \\
\hline Érdekes, sokszínű & 9 & 5 & 14 \\
\hline A fejlődési lehetőségek miatt & 10 & 4 & 14 \\
\hline Meg tudja valósítani önmagát & 3 & 0 & 3 \\
\hline A szakmai színvonal miatt & 1 & 2 & 3 \\
\hline Gyorsan tud alkalmazkodni & 2 & 0 & 2 \\
\hline Összes „igenlő” említés & 166 & 60 & 226 \\
\hline
\end{tabular}

72 Forrás: FónAl (2014): i. m., 113.

73 Forrás: FónAl (2014): i. m., 115. 